\title{
Late Triassic ostracods from the Lycian Nappes, southwestern Turkey: implications on taxonomy and palaeobiogeographical distribution
}

\author{
Marie-Béatrice Forel ${ }^{1, *}$ and Patrice Moix ${ }^{2}$ \\ ${ }^{1}$ Muséum national d'Histoire naturelle, CR2P UMR7207, MNHN-CNRS-SU, 8, rue Buffon (CP38), 75005 Paris, France \\ 2 Rue de la Combe 55, 1969 Eison, Switzerland
}

Received: 15 December 2019 / Accepted: 3 August 2020

\begin{abstract}
The first ostracods known from the Lycian Nappes in southwestern Turkey are here reported, adding to the scientific understanding of marine ostracods during the Cordevolian, early Carnian, Late Triassic. The Karapınar Formation exposed at the Ağılıvası Yayla section yielded five species, including the typical Late Triassic Mirabairdia longispinosa Kristan-Tollmann, Nodobairdia mammilata Kollmann and Polycope pumicosa schleiferae Kozur. Their taxonomy is discussed and the ontogenetic development of Nodobairdia mammilata is described for the first time. In spite of the limited significance of this poor fauna for palaeoenvironment reconstitution, it points to a deposition in the offshore subtidal zone under moderate water depth, in line with previous interpretations. The palaeobiogeographical distribution of marine ostracods during the Late Triassic is updated and discussed. It implies that communication ways between the Palaeotethys and Neotethys oceans were already opened during the Cordevolian, slightly earlier than the Julian as previously proposed.
\end{abstract}

Keywords: ostracods / Carnian / Lycian Nappes / Turkey / taxonomy / palaeobiogeography

\begin{abstract}
Résumé - Ostracodes du Trias supérieur des Nappes Lyciennes, Turquie du sud-ouest: implications taxinomiques et paléobiogéographiques. Les premiers assemblages d'ostracodes connus des Nappes Lyciennes au sud-ouest de la Turquie sont ici rapportés, apportant à la compréhension scientifique des ostracodes marins du Cordévolien, Carnien inférieur, Trias supérieur. La Formation Karapınar affleurant à Ağılıovası Yayla a livré cinq espèces, dont Mirabairdia longispinosa Kristan-Tollmann, Nodobairdia mammilata Kollmann et Polycope pumicosa schleiferae Kozur, typiques du Trias supérieur. Leur taxinomie est discutée et le développement ontogénétique de Nodobairdia mammilata est décrit pour la première fois. En dépit des limites de cette faune pauvre pour la reconstitution du paléoenvironnement, elle indique un milieu de dépôt dans la zone subtidale sous une colonne d'eau modérée, en accord avec les interprétations antérieures. La distribution paléobiogéographique des ostracodes marins au Trias supérieur est mise à jour et discutée. Elle implique que les voies de communication entre les océans Paléotéthys and Néotéthys étaient ouvertes dès le Cordévolien, légèrement plutôt qu'au Julien comme proposé auparavant.
\end{abstract}

Mots clés : ostracodes / Carnien / Nappes Lyciennes / Turquie / taxinomie / paléobiogéographie

\section{Introduction}

The Triassic period is one of the most significant intervals of time in the macroevolutionary history of organisms, with the rise of the modern fauna and the emergence of modern ecosystems in sea and on land (e.g. Spekoski, 1984; Van Valen, 1984; Brusatte et al., 2011; Chen and Benton, 2012; Benton

\footnotetext{
*Corresponding author: marie-beatrice.forel@mnhn.fr
}

et al., 2013). Most of the new predators later involved in the Mesozoic marine revolution (Vermeij, 1977), such as predatory gastropods, decapods, neopterygian fishes and marine reptiles, were already established in the Triassic (e.g. Chen and Benton, 2012 and references therein for a review). Middle and Late Triassic occurrences of drill holes on mollusks, brachiopods (Klompmaker et al., 2016) and ostracods (Forel et al., 2018) are rare but witness the establishment of typically Mesozoic drilling activity as early as Anisian, Middle Triassic. 
Ostracods are millimetre-size crustaceans that today live in various aquatic environments, from temporary freshwater ponds to hydrothermal sources or cold methane seep sites (e.g. Horne et al., 2002; Maddocks, 2005; Karanovic, 2012; Yasuhara et al., 2018). The deepest known living species has been reported from $9307 \mathrm{~m}$ water depth (Brandão et al., 2019). Ostracods have dwelt in marine waters since the Early Palaeozoic (e.g. Salas et al., 2007; Siveter, 2008). They were significantly affected by the end-Permian crisis and their recovery is considered as complete during the Anisian, Middle Triassic (Crasquin-Soleau et al., 2007; Crasquin and Forel, 2015). The Triassic period is of paramount importance in their macroevolution with the turnover from the Palaeozoic to the Meso-Cenozoic faunas (e.g. McKenzie, 1982; Crasquin-Soleau et al., 2007; Crasquin and Forel, 2015). However, this period stays enigmatic with the challenging temporary dominance of heavily sculpted Bairdiidae (e.g. Kollmann, 1960, 1963; Bolz, 1971a, b; Kristan-Tollmann, 1978) or residual occurrence of Palaeozoic taxa in deep waters up to the Carnian (Forel et al., 2019a). These features, together with the still poor understanding of their geographical, environmental and taxonomic distribution, challenge our understanding of their survival mechanisms and diversity structuration during the Triassic, prior to their Mesozoic rediversification.

Here we report on ostracods from the Cordevolian, early Carnian, Late Triassic, of the Lycian Nappes (Karadağ Unit, Karapınar Formation) in southwestern Turkey. Five species are recognized, of which three are already known from the Upper Triassic marine successions: Mirabairdia longispinosa Kristan-Tollmann (1978), Nodobairdia mammilata Kollmann (1963) and Polycope pumicosa schleiferae Kozur in Bunza and Kozur (1971). The taxonomy of the species is discussed and the development of Nodobairdia mammilata is described for the first time, with the identification of five ontogenetic stages. This faunule from the northern margin of the Neotethys adds new data to the knowledge of the palaeobiogeographical distribution of ostracods during the Late Triassic. The comparison of their updated distribution through time with the three main hypotheses of the origin of Tethyan ostracods, here termed "western America", "eastern Tethys" and "western Tethys" (e.g. Bate, 1977; Kristan-Tollmann and Tollmann, 1981, 1982; Kristan-Tollmann, 1986a, b, 1988a; Lord, 1988; Ketmuangmoon et al., 2018), documents a mixture of distribution pathways depending on the taxonomic level under scrutiny. The large distribution of Mirabairdia longispinosa and Nodobairdia mammilata in the Cordevolian, early Carnian, implies that they might have radiated at the end of the Ladinian and that communication ways between the Palaeotethys and Neotethys oceans were opened earlier than generally proposed (Julian; e.g. Kozur, 2000; Stampfli and Kozur, 2006; Moix et al., 2007, 2013).

\section{Geological setting and stratigraphy}

The studied area was described in details by Moix et al. (2013): only a short overview is provided here and the reader is referred to this key contribution and references therein for all tectonostratigraphic details on the Lycian Nappes.

\subsection{The Lycian Nappes}

The Lycian Nappes represent a vast area in southwestern Turkey between the Menderes Massif to the northwest and the Beydağları platform to the southeast (Fig. 1). They are subdivided into three main tectonic units (de Graciansky, 1968, 1972; Brunn et al., 1971; Bernoulli et al., 1974; Poisson, 1977), in ascending order:

- The autochthonous series of the Menderes Massif and the Beydağları/Susuz Dağ/Göcek domains;

- The intermediate complex, which is composed of imbricated thrust sheets, viz. Karadağ, Teke Dere, Haticeana Dağ and Köyceğiz units;

- The peridotite Marmaris Nappe, of Late Cretaceous age, at the top of the tectonic pile.

The Lycian Nappes are composed of the Bodrum, Domuzdăg, Dumanlıdağ, Gülbahar, Marmaris and Tavas nappes (Senel et al., 1994; Fig. 1). The Tavas Nappe is itself composed of the Karadağ and Teke Dere units (Fig. 2).

The Karadağ Unit is of Middle Carboniferous to Late Triassic age and is composed of bioclastic limestones with sandy and pelitic intercalations (de Graciansky, 1968, 1972; see Moix et al., 2013 for further precisions). Thick outcrops of quartzites were attributed to the Early Triassic or late Ladinian (de Graciansky, 1972; Bernoulli et al., 1974). The Karadağ Unit is subdivided into six formations, in ascending order (Senel et al., 1994; Fig. 2): Sazak Fm. (possibly Late Devonian shales and limestones, not shown in Fig. 2), Kiloluk Fm. (Middle Carboniferous bioclastic limestones, dolomites and dolomitic limestones, not shown in Fig. 2), Akkavak Fm. (Early Permian crystalline limestones, dolomites and shales), Saritas Fm. (possibly late Anisian to early Ladinian sandstones), Karapınar Fm. (black limestones with Middle Triassic foraminifers and early Carnian conodonts; Moix et al., 2013) and Belenkavak Fm. (Carnian-Norian sandstones, siltstones and shales).

The Teke Dere Unit is of Early and Late Permian age and is composed of white dolomites and massive limestones followed by green arkosic sandstones and greywackes (de Graciansky, 1968, 1972). Pillow-lavas, black and russet folded radiolarites and Permian limestones locally intersperse the green arkoses. This interval is capped by Late Permian dolomites and limestones, unconformably overlain by the red continental to shallow-marine Cenger Fm. of Late Triassic age as shown by lungfish and reptile remains (Monod et al., 1983; Buffetaut et al., 1988). These red conglomerates, sandstones and siltstones are molassic deposits followed by a thick carbonate sequence ranging from the Triassic to the Late Cretaceous (A $\breve{g}$ açli and Badada $\breve{g}$ formations), which is itself overlain by a Late Paleocene to Lutetian flysch (Senel, 1997). The Teke Dere Unit is composed of the following formations in ascending order (Senel et al., 1994; Fig. 2): Çatakdere Fm. (crystalline limestones), Incirbeleni Fm. (shales, sandstones, limestone lenses, lydites and volcanics) and Nisangahtepe Fm. (dolomites and limestones). These three formations were considered as early to middle Wordian in age, but Kozur et al. (1998) indicated a Mississippian age for the Incirbeleni Fm. and microfauna and microflora from the Nisangahtepe Fm. 


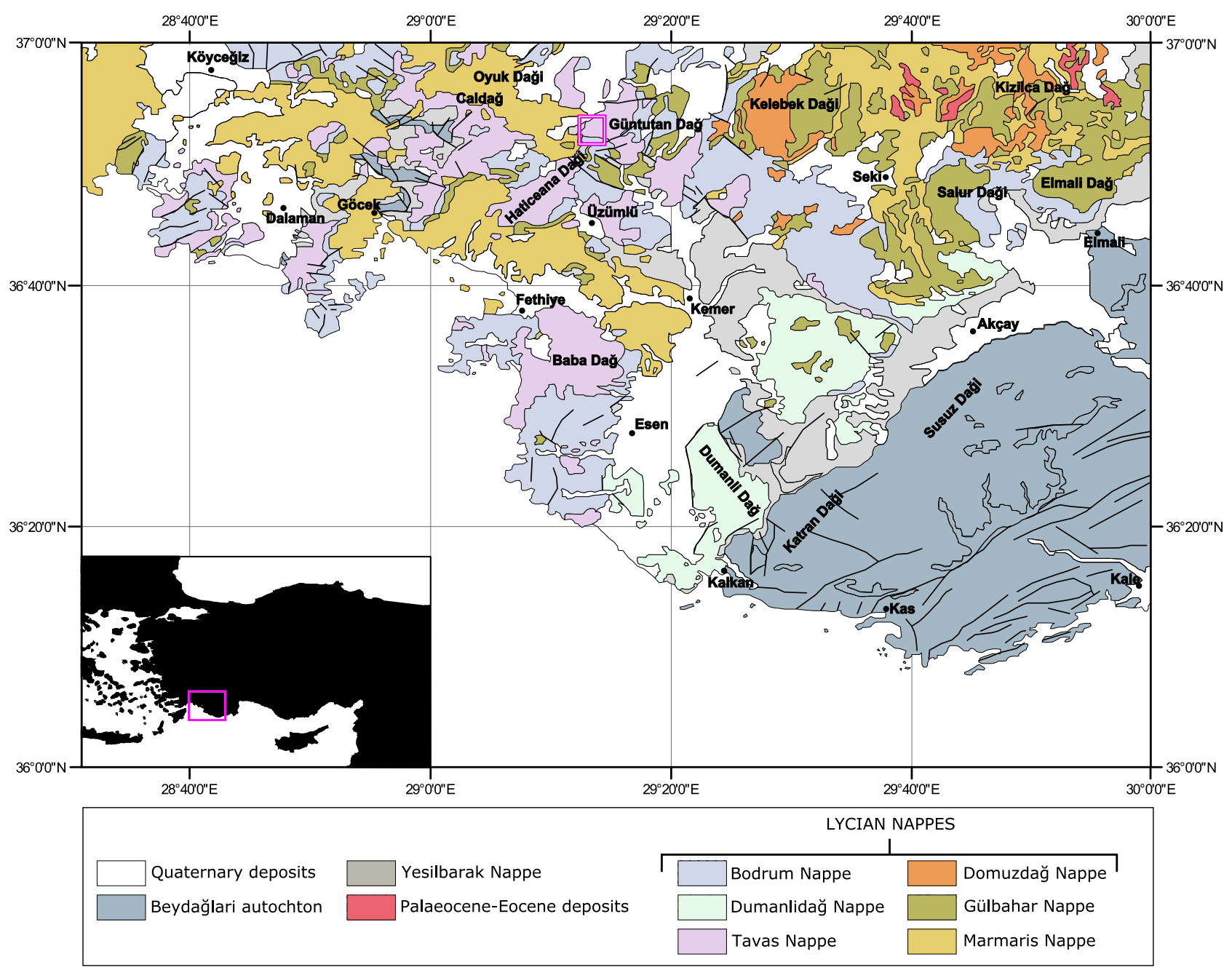

Fig. 1. Simplified structural map of southwestern Turkey showing the tectonic units of the Fethiye quadrangle (modified from Senel, 1997). The pink square indicates the location shown in Figure 2.

rather point to a Kubergandian age (Tethyan equivalent of the Roadian; Vachard and Moix, 2013).

\subsection{The Ağılıovası Yayla section}

The investigated area is located north of the Teke Peninsula in southwestern Turkey, northeast of Fethiye Gulf and close to the road between Fethiye and Çameli (Fig. 1). The A $\breve{g}_{1}$ lıovası Yayla series are located between 1600 and $2000 \mathrm{~m}$ of altitude, $4 \mathrm{~km}$ south of Tascilar village, north of the Karadag $(2233 \mathrm{~m})$ and about $1 \mathrm{~km}$ east of a pasture known as A $\breve{g}_{1}$ liovasi Yayla. The composite succession of the A ğıliovası Yayla section permits the recognition of the Karadag and Teke Dere units (Fig. 2). All carbonate microfacies correspond to shallow inner-ramp deposits that have been little displaced to preserved as in situ thanatocenoses or proximal tempestites (Moix et al., 2013).

The oldest shallow marine sediments in the Ağllovas Yayla area belong to the Kiloluk Fm. The base of the sequence is composed of dolomites, cherty limestones and bioclastic limestones that contain early Kasimovian fusulinids (Vachard and Moix, 2011; Moix et al., 2013). Recent tectonics brought the Late Carboniferous succession close to a $160-\mathrm{m}$ thick platform-like development of Early Permian to Late Triassic age.

The Ağılıovası Yayla autochthonous series start with grey fusulinid-rich limestones. It is transitional to alternating thinbedded black limestones, massive grey to black limestones, middle-bedded sandy limestones with pelitic horizons, thickbedded black laminated limestones and thin-bedded black limestones interspersed by argilites (Akkavak Fm.). All fossil assemblages indicate a Sakmarian age (Moix et al., 2013). It is followed by the Saritas Fm., which is a thick-bedded interval of white quartzites. It is capped by the Karapınar Fm., composed of thick-bedded gray limestones and thin-bedded bioclastic black nodular limestones, locally with cherts. The limestones levels indicate a Middle-Late Triassic age (Moix et al., 2013). The upper part of the section is marked by the siliciclastic Belenkavak Fm., corresponding to a wildflyschlike sequence composed of shales, silstones, sandstones, conglomerates, with various blocks of Permian age (de Graciansky, 1972; Vachard and Moix, 2011).

The sample investigated in this work (labelled 328/07) belongs to the Karadag Unit and was previously studied by 
M.-B. Forel and P. Moix: BSGF 2020, 191, 30

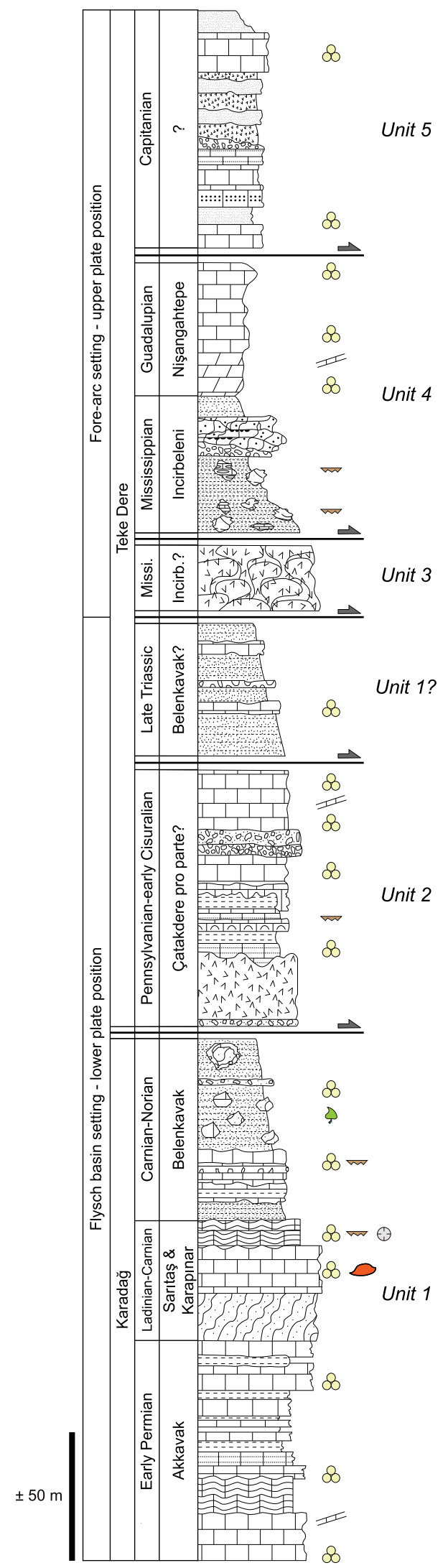

\begin{tabular}{|c|c|c|c|}
\hline 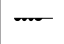 & Hard ground & 厓 & Radiolarites (lydites) \\
\hline Fis & Quartzites & $\begin{array}{l}\text { की } \\
\text { solo }\end{array}$ & Cherty limestones \\
\hline${ }_{11}$ & Marly limestones & $\begin{array}{r}8.80 \\
0.0 \\
00\end{array}$ & Breccias \\
\hline 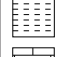 & Shales & ${ }^{+1}$ & Neritic limestones \\
\hline …: & Detritic limestones & 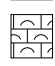 & Shelly limestones \\
\hline$y$ & Dolomite & $\sim$ & Unconformity \\
\hline 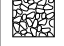 & Conglomerates & $m$ & Conodonts \\
\hline$\left[\begin{array}{ll}\hat{n} \\
\hat{\lambda} & \hat{n} \\
\Lambda & 1 \\
1\end{array}\right]$ & Lava (sometimes pillows) & D) & Plant remains \\
\hline 臣置 & Pelagic limestones & 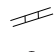 & Algae \\
\hline$m$ & Siltstones, greywackes & $\theta$ & Corals \\
\hline & tuffites,calciturbidites & 8 & Foraminifers \\
\hline 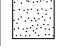 & Sansdstone & $\infty$ & Ostracods \\
\hline
\end{tabular}

Fig. 2. Synthetic composite lithostratigraphic succession of the A $\breve{1} 1$ lovası Yayla section (modified after Moix et al., 2013) and position of the studied sample. 
Moix et al. (2013). It is issued from dark limestones at the top of the Karapınar Fm. (Fig. 2) that yielded Pseudofurnishius murcianus murcianus van den Boogaard (1966), a conodont indicative of the Cordevolian, early Carnian, Late Triassic (based on the three-folded Carnian subdivision of Kozur and Mostler, 1994, 1996; Kozur, 2003). This conodont is also a typical indicator for the Neotethyan domain, showing that the Karadağ Unit belongs to the Cimmerian Taurus terrane and was part of the northern passive margin of the Neotethys (Moix et al., 2013). Ostracods have been mentioned in this sample by Moix et al. (2013) with two specimens illustrated and identified as "Sculptured Bairdiidae" and "Polycopsis n. sp. ex gr. cincinnata (Apostolescu)". The occurrence of other sculptured bairdiids was mentioned and discussed in terms of palaeoenvironmental implication in Moix et al. (2013) but no taxonomic list was provided.

\section{Material and methods}

The sample 328/07 was processed using acetic acid for conodont extraction (Moix et al., 2013) and also yielded an ostracod faunule of eight specimens representing five species distributed into four genera (Plate 1). Although not abundant, their preservation is good enough to identify three species already known from the Late Triassic, viz. Mirabairdia longispinosa Kristan-Tollmann (1978), Nodobairdia mammilata Kollmann (1963) and Polycope pumicosa schleiferae Kozur in Bunza and Kozur (1971). The other two species are kept in open nomenclature because of the lack of material and of distinctive characters.

In this contribution, we follow the general classification of Moore (1961) and Horne et al. (2002). For the three species already known during the Triassic, we provide and discuss the complete list of synonyms and kresonyms in order to build a suitable basis for the palaeobiogeographical investigation performed here. The height/length diagram of Nodobairdia mammilata Kollmann (1963) gathers the dimensions of all specimens from the literature and this work (Fig. 3). In this diagram, right and left valves are distinguished for isolated valves and complete carapaces, following the method of Urlichs (1971), Harloff (1993) and Forel et al. (2019b) for instance. For each of the species scrutinized in this work, we follow the updated stratigraphic framework available on the Paleobiology Database (accessed on the 01/10/2019) and their original and revised stratigraphic information are summarized in Table 1.

An important point in the discussion of the palaeobiogeographical implications of the ostracods from the Lycian Nappes is which is the adopted definition of the Carnian. The subdivisions of the Carnian stage have been a matter of debate, between a two-fold and a three-fold Carnian (see Chen et al., 2016 and Rigo et al., 2018 for recent summaries). The three-fold Carnian subdivision is here followed and the recovered species are of Cordevolian age, early Carnian, as shown by the occurrence of the conodont Pseudofurnishius murcianus murcianus (Moix et al., 2013). All figured specimens are deposited in the micropalaeontology collections of the Muséum national d'Histoire naturelle (Paris), under catalogue numbers MNHN.F.F63332-MNHN.F. F63339.

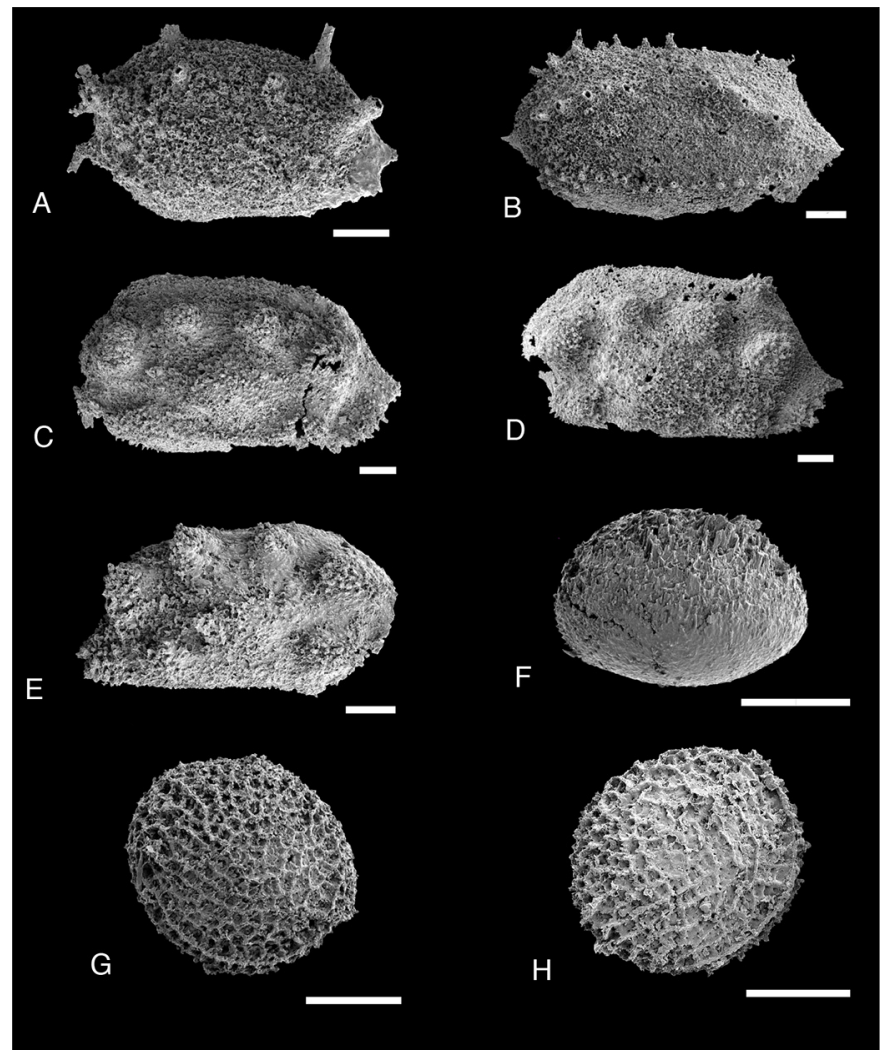

Plate 1. Ostracods from the sample 328/07, Karapınar Formation, Lycian Nappes, southwestern Turkey, Cordevolian, Early Carnian, Late Triassic (MNHN: Muséum national d'Histoire naturelle, Pairs). A: Mirabairdia longispinosa Kristan-Tollmann (1978), lateral view of a left valve, MNHN.F.F63332; B: Mirabairdia sp., lateral view of a left valve, MNHN.F.F63333; C-E: Nodobairdia mammilata Kollmann (1963); C: lateral view of a left valve, MNHN.F.F63334; D: lateral view of a right valve, MNHN.F.F63335; E: lateral view of a right valve, MNHN.F.F63336; F: Hungarella sp.: lateral view of a left valve, MNHN.F.F63337; G, H: Polycope pumicosa schleiferae Kozur in Bunza and Kozur (1971); G: lateral view of a right valve, MNHN.F. F63338; D: lateral view of a left valve, MNHN.F.F63339. All scale bars are $100 \mu \mathrm{m}$.

\section{Systematic palaeontology (by Marie-Béatrice Forel)}

Class Ostracoda Latreille (1806)

Subclass Podocopa Müller (1894)

Superfamily Bairdioidea Sars (1887)

Family Bairdiidae Sars (1887)

Subfamily Bairdiinae Sars (1923)

Genus Mirabairdia Kollmann (1963)

1973a Vavilovella Kozur: 21-24, pl. 3, figs. 4, 5.

Type species. Mirabairdia pernodosa Kollmann (1963) by original designation.

Preliminary remarks. Vavilovella Kozur (1973a) (type species: Vavilovella psychrosphaerica Kozur (1973a); Sevatian, late Norian, Austria) was erected to accommodate bairdiids with "dorsal outline clearly divided into three parts; 


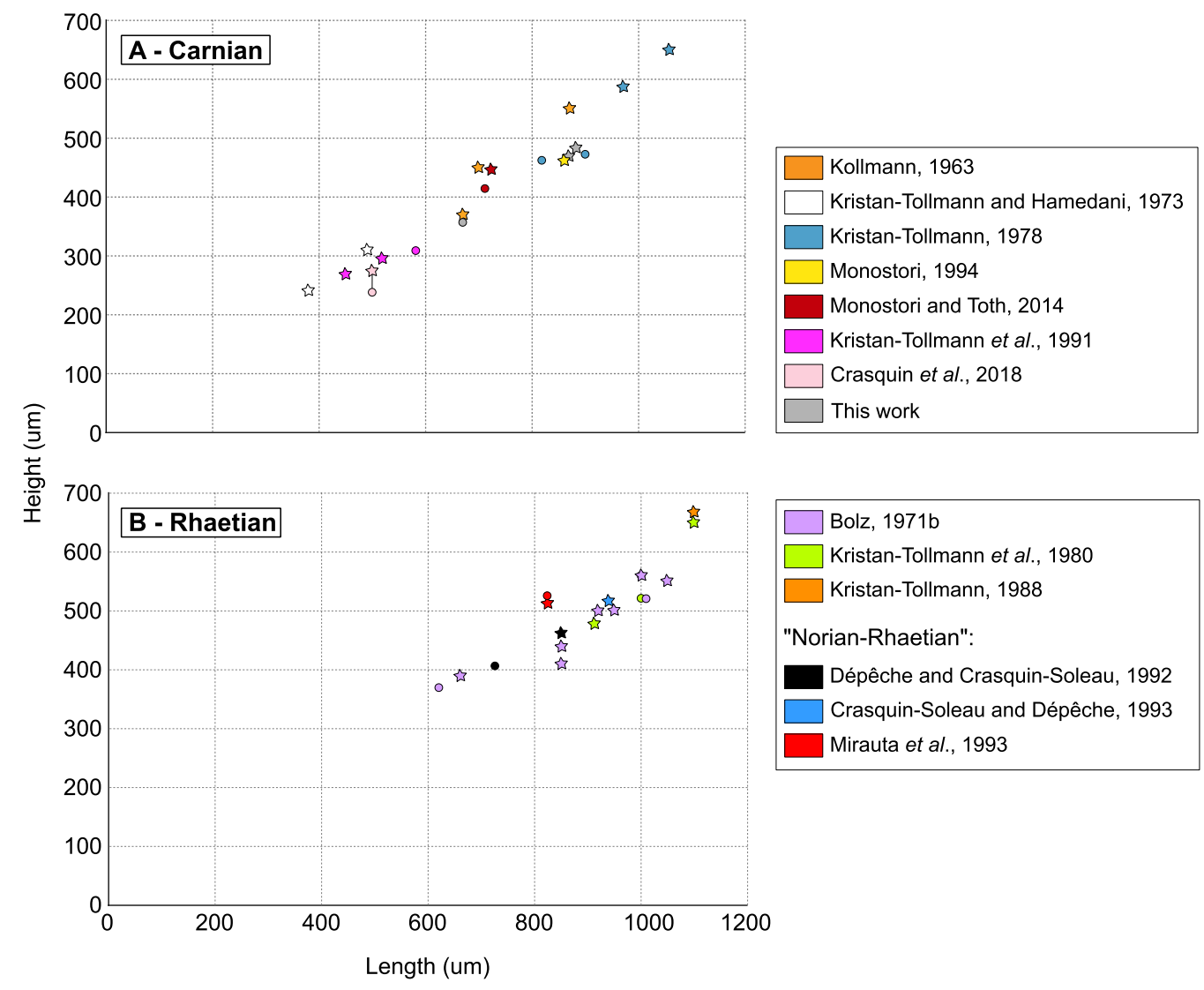

Fig. 3. Height/Length scatter plot of Nodobairdia mammilata Kollmann (1963) for the Carnian (A) and Rhaetian (with "Norian-Rhaetian"; B). The dimensions of right and left valves of the complete carapace are linked. Right valves and left valves are represented respectively by circles and stars.

Table 1. Updated stratigraphic information of studied and cited species, following the Palaeobiology Database, accessed on the $01 / 10 / 2019$.

\begin{tabular}{|c|c|c|c|}
\hline Species and reference considered & Occurrence in original reference & PBDB update & This work \\
\hline Mirabairdia pernodosa Kollmann (1963) & Ladinian-lower Carnian & Julian-Tuvalian, Carnian & Cordevolian-Tuvalian, Carnia \\
\hline $\begin{array}{l}\text { Mirabairdia longispinosa } \\
\text { Kristan-Tollmann (1978) } \\
\text { in Liebermann (1979) }\end{array}$ & $\begin{array}{l}\text { "Niveau mit Trachyceras aon", } \\
\text { Julian, middle Carnian }\end{array}$ & - & Cordevolian, early Carnian \\
\hline Nodobairdia mammilata Kollmann (1963) & Ladinian & $\begin{array}{l}\text { aon subzone, Julian, } \\
\text { middle Carnian }\end{array}$ & Cordevolian, early Carnian \\
\hline $\begin{array}{l}\text { Nodobairdia mammilata Kollmann (1963) } \\
\text { in Liebermann (1979) }\end{array}$ & Julian, middle Carnian & $\begin{array}{l}\text { aon subzone, Julian, } \\
\text { middle Carnian }\end{array}$ & Cordevolian, early Carnian \\
\hline $\begin{array}{l}\text { Triebelina (Nodobairdia) } \\
\text { triassica Bolz (1971a) }\end{array}$ & Norian-Rhaetian & Rhaetian & Rhaetian \\
\hline Triebelina sp. G in Bolz (1971a) & Norian-Rhaetian & Rhaetian & Rhaetian \\
\hline
\end{tabular}

anterior end terminated by long thorns; surface occupied by long, forked thorns, with small nodules between them" (Kozur, 1973a; translated from german). Kozur (1973a) distinguished Vavilovella from Mirabairdia Kollmann (1963) by the extreme sculpture of Vavilovella, all lateral elements being transformed into thorns while they are only single spines in Mirabairdia. Kristan-Tollmann (1978) underlined that the general arrangement of the ornaments in the two genera is strictly similar and that their morphology, varying from short lobes to pedunculated nodes or spines, should only be used for specific separation. Kristan-Tollmann (1978) therefore considered Vavilovella as a junior synonym of Mirabairdia. This opinion has been followed in all publications since the work of Kristan-Tollmann (1978) and is followed here.

\section{Mirabairdia longispinosa Kristan-Tollmann (1978)}

(Plate 1A)

1978 Mirabairdia longispinosa Kristan-Tollmann: 94-96, pl. 3, figs. 1-3; pl. 7, fig. 5 . 
1979 Mirabairdia longispinosa Kristan-Tollmann; Liebermann: 106.

2018 Mirabairdia longispinosa Kristan-Tollmann; Forel et al.: 10, figs. 4.20, 4.21 .

Material. One left valve.

Dimensions. $\mathrm{L}=518 \mu \mathrm{m}, \mathrm{H}=327 \mu \mathrm{m}, \mathrm{H} / \mathrm{L}=0.63$ (this material).

Occurrences. South Tyrol, Italy, Cordevolian, early Carnian, Late Triassic (Kristan-Tollmann (1978)); Cave del Predil (Raibl), Italy, Julian Alps, Cordevolian, early Carnian, Late Triassic (Liebermann, 1979; see stratigraphic update in Tab. 1); Tavusçayiri Block, Sorgun Ophiolitic Mélange, Huğlu Tuffite, southern Turkey, Spongotortilispinus moixi radiolarian Zone, lower Tuvalian, late Carnian, Late Triassic (Forel et al., 2018); sample 328/07, Karapınar Formation, Karadağ Unit, A ğıliovası Yayla section, Lycian Nappes, southwestern Turkey, Cordevolian (Pseudofurnishius murcianus murcianus conodont), early Carnian, Late Triassic (this work).

Remarks. In the studied sample, Mirabairdia longispinosa occurs as a single $\mathrm{LV}$, the dimensions of which indicate that it is a relatively young juvenile (see below for further discussion). Despite these abundance and size limitations, the lateral outline, absence of nodes and morphology of the horns exclude this species from Mirabairdia pernodosa Kollmann (1963) (Carnian, Late Triassic, Austria), Mirabairdia plurinodosa Mette et al. (2014) and Mirabairdia praepsychrosphaerica Mette et al. (2014) (the latter two species being from Pelsonian, middle Anisian, Middle Triassic, Austria).

The specimen from the Lycian Nappes displays:

- Two dorsal thorns;

- A subdorsal row of three thorns, the posterior one being thicker, and a relatively large pedunculated anterior wart;

- An anterior bifurcated spine;

- Three poorly preserved sub-ventral warts.

This species is therefore attributed without doubt to the typically Carnian Mirabairdia longispinosa Kristan-Tollmann (1978) that is diagnosed by a lateral ornamentation made of thorns and warts, while it is exclusively composed of thorns in Mirabairdia psychrosphaerica (Kozur, 1973a) known from the Rhaetian, Late Triassic, of Austria. The present specimen is much smaller than the holotype $(\mathrm{L}=1130 \mu \mathrm{m}, \mathrm{H}=580 \mu \mathrm{m}$; Kristan-Tollmann (1978)) and corresponds to a relatively young instar. Only few specimens of this species are known so that its ontogenetic development is complex to assess. However, the difference in $\mathrm{H} / \mathrm{L}$ ratio between the holotype $(0.51)$ and the present specimen (0.63) indicates that one feature of the ontogeny of Mirabairdia longispinosa is an overall elongation of the carapace. Furthermore, the occurrence of already well-developed diagnostic ornamental features on the juvenile from the Lycian Nappes indicates that they appear relatively early in the ontogeny of this species.

\section{Mirabairdia sp.}

(Plate 1B)

2013 Sculptured Bairdiidae; Moix et al.: pl. 5, fig. 6.

Material. One left valve.

Dimensions. $\mathrm{L}=750 \mu \mathrm{m}, \mathrm{H}=437 \mu \mathrm{m}, \mathrm{H} / \mathrm{L}=0.58$.

Occurrences. Sample 328/07, Karapınar Formation, Karadă Unit, Ağılıovası Yayla section, Lycian Nappes, southwestern Turkey, Cordevolian (Pseudofurnishius murcianus murcianus conodont), early Carnian, Late Triassic (Moix et al., 2013; this work).

Remarks. The present specimen was illustrated in Moix et al. (2013; pl. 5, fig. 6) with the following description: "Sculptured Bairdiidae, left valve, former ventral rib and former elongated oblique anterodorsal and posterordorsal ribs disintegrated in lines of short hollow spines, such a feature occurs only in such sculptured Bairdiidae which lived below the storm wave base" (p.433). It was only identified at the familial level, without discussion on possible generic attribution. It is here attributed to Mirabairdia.

Mirabairdia sp. is a thin and delicate LV. The DB bears a series of straight spines that apparently do not extend to the PDB and only slightly to the ADB. The lateral surface is characterized by:

- A series of small hollow spines in the ventro-lateral area, parallel to the ventral margin, extending from the AVB to the PVB;

- Two straight rows of four larger hollow spines below the antero-dorsal and postero-dorsal angles, respectively bent anteriorly and posteriorly.

This lateral ornamentation relates Mirabairdia sp. to Mirabairdia pernodosa Kollmann (1963) from the Carnian of the Alps (Kollmann (1963); see stratigraphic update in Tab. 1). However, Mirabairdia sp. lacks the horizontal and vertical rows of spines in the median and dorsal areas developed on Mirabairdia pernodosa. The morphology of this species from the Lycian Nappes mainly differs from all other Mirabairdia species from the literature by its more delicate and thinner lateral ornaments, which could relate to the fact that the obtained LV may be a relatively young instar. This hypothesis is reinforced by the comparison of its dimensions with that of species from the literature:

- Mirabairdia pernodosa Kollmann (1963):

Adult: $\mathrm{L}=810-820 \mu \mathrm{m}, \mathrm{H}=440-460 \mu \mathrm{m}$;

Juveniles: $\mathrm{L}=670-700 \mu \mathrm{m}, \mathrm{H}=370-410 \mu \mathrm{m}$;

- Mirabairdia longispinosa Kristan-Tollmann (1978): Adult: $\mathrm{L}=1130 \mu \mathrm{m}, \mathrm{H}=580 \mu \mathrm{m}$;

- Mirabairdia plurinodosa Mette et al. (2014):

$\mathrm{RV}: \mathrm{L}=920-1130 \mu \mathrm{m}, \mathrm{H}=460-560 \mu \mathrm{m}$;

LV: $L=950-1070 \mu \mathrm{m}, \mathrm{H}=460-570 \mu \mathrm{m}$;

- Mirabairdia praepsychrosphaerica Mette et al. (2014):

$\mathrm{RV}: \mathrm{L}=1120-1270 \mu \mathrm{m}, \mathrm{H}=490-530 \mu \mathrm{m}$;

LV: $L=1120-1270 \mu \mathrm{m}, \mathrm{H}=520-640 \mu \mathrm{m}$.

This species is new to science but its diagnostic characters cannot be reliably described until more material is found.

Until now, the ontogeny of Mirabairdia species stays poorly described. Kozur (1973a) indicated that juveniles of Mirabairdia psychrosphaerica (Kozur, 1973a) from the Rhaetian of Austria slightly differ from adults in being squat, with anterior extremity longer, more weakly rounded and ventral margin straighter, with short dorso-median, ventromedian and antero-ventral spines. Juveniles of Mirabairdia pernodosa illustrated in Kollmann (1963) show that large nodules bearing smaller nodules are already present in the earliest juvenile recovered. Mirabairdia sp. is devoid of large 
nodules, which would imply that small nodules may appear earlier than larger ones during the ontogenetic development and/or may be diagnostic features of the new species. Only additional material allowing for the characterization of the ontogenetic development of this species will clarify this issue.

Genus Nodobairdia Kollmann (1963)

Type species. Nodobairdia mammilata Kollmann (1963) by original designation.

Preliminary remarks. The taxonomic history of Triassic sculptured Bairdiidae is complex with a strong volatility of opinions on the significance of characters used for their classification. Nodobairdia Kollmann (1963) was erected to accommodate bairdiids with four large sub-dorsal warts and a longitudinal latero-ventral ridge undivided or divided into three parts (Kollmann (1963)). Contrary to the generic scheme established by Kollmann (1963) that was later followed by diverse authors, Bolz (1971a, b) considered that the presence/ absence of marginal ornamentations is more significant than their morphology (e.g. nodular, annular, spinose). In Bolz generic scheme, Nodobairdia is considered as a subgenus of the extant genus Triebelina van den Bold (1946). KristanTollmann (1978), more recently followed by Mette et al. (2014), suggested that the ornamentation of Nodobairdia and Mirabairdia shows a gradual pattern so that these genera may be synonyms. It is beyond the scope of the intention of this paper and its material to attempt a revision of the Bairdiidae at the generic level. The important variations of the opinions of the diverse authors on the generic classification of Bairdiidae resulted in an intricate situation, with the alternative use of Kollmann and Bolz schemes by the same authors, for instance in Urlichs (1972), Hillebrandt et al. (2007, 2013) and Urlichs and Krystyn (2016). To avoid adding noise factor to the already confuse classification of Triassic ornate Bairdiidae and until their systematic and phylogeny are clarified, the generic scheme of Kollmann (1963) is followed in considering primary ornamentation as relevant generic character, owing that ornamentation is widely used as generic marker for other families (e.g. Trachyleberididae; Moore (1961); more recently Warne and Whatley, 2016).

\section{Nodobairdia mammilata Kollmann (1963)}

(Plates 1C-E)

1963 Nodobairdia mammilata Kollmann: 174, 175, pl. 7, figs. 6-15.

1971a Triebelina sp. G; Bolz: pl. 2, fig. 9.

1971b Triebelina (Nodobairdia) triassica Bolz: 216-218, pl. 16, figs. 229-232.

1971 Nodobairdia mammilata Kollmann; Kristan-Tollmann: 61, pl. 1, fig. 1.

non 1973 Nodobairdia mammilata Kollmann; KristanTollmann and Hamedani: pl. 12, fig. 9, pl. 13, fig. 1.

1978 Nodobairdia mammilata Kollmann; Kristan-Tollmann: 84, pl. 8, figs. 1-6.

1979 Nodobairdia mammilata Kollmann; Liebermann: $105,106$.

1980 Nodobairdia mammilata Kollmann; Kristan-Tollmann et al.: 185, pl. 7, figs. 11-13.

1986b Nodobairdia mammilata Kollmann; Kristan-Tollmann: 209, 210, fig. 4.

1988a Nodobairdia mammilata Kollmann: Kristan-Tollmann: fig. 6/6.
1991 Nodobairdia mammilata Kollmann; Kristan-Tollmann et al.: 201, pl. 1, figs. 1-3.

1992 Nodobairdia mammilata Kollmann; Dépêche and Crasquin: 2, figs. 1-4.

1993 Nodobairdia mammilata Kollmann; Crasquin and Dépêche: pl. 1, fig. 12.

1993 Nodobairdia mammilata Kollmann; Mirăuță et al.: 95, pl. 3, figs. 22a, b.

1994 Nodobairdia mammilata Kollmann; Monostori: 316, 318, fig. $4 / 3$.

2010 Nodobairdia mammilata Kollmann; Zorn: 271, pl. 7, figs. 8-11.

2014 Triebelina (Nodobairdia) mammilata (Kollmann); Monostori and Tóth: 28, pl. 2, figs. 9, 10.

2015 Nodobairdia mammilata Kollmann; Hausmann and Nützel: 241.

2016 Nodobairdia triassica (Bolz); Urlichs and Krystyn: 21.

2018 Nodobairdia mammilata Kollmann; Crasquin et al.: 137, fig. $7 \mathrm{G}$.

Material. Two left valves, one right valve (this material).

Dimensions. Fig. 3.

Occurrences. South Tyrol, Italy, Cordevolian, early Carnian, Late Triassic (Kollmann (1963); Kristan-Tollmann, 1971; Zorn, 2010; see stratigraphic update in Tab. 1); Northern Calcareous Alps, Rhaetian, Late Triassic (Bolz, 1971a, b; Urlichs and Krystyn, 2016; see stratigraphic update in Tab. 1); South Tyrol, Italy, Cordevolian, early Carnian, Late Triassic (Kristan-Tollmann (1978)); Cave del Predil (Raibl), Italy, Julian Alps, Cordevolian, early Carnian, Late Triassic (Liebermann, 1979; see stratigraphic update in Tab. 1); Iran, Rhaetian, Late Triassic (Kristan-Tollmann et al., 1980; Kristan-Tollmann, 1988a); Australia, early Norian, Late Triassic (Kristan-Tollmann, 1986b); Hungary, upper JulianTuvalian, middle-late Carnian, Late Triassic (KristanTollmann et al., 1991; Monostori, 1994); Australia, late Norian-mid-Rhaetian, Late Triassic (Dépêche and Crasquin, 1992; Crasquin and Dépêche, 1993); Hungary, CarnianRhaetian, Late Triassic (Monostori and Tóth, 2014); Stuores Wiesen, Italy, Carnian, Late Triassic (Hausmann and Nützel, 2015); Sicily, Tropites dilleri zone, Tuvalian, late Carnian, Late Triassic (Crasquin et al., 2018); sample 328/07, Karapınar Formation, Karadağ Unit, Ağılıovası Yayla section, Lycian Nappes, southwestern Turkey, Cordevolian (Pseudofurnishius murcianus murcianus conodont), early Carnian, Late Triassic (this work).

Remarks. We follow Kristan-Tollmann (1978) in considering Triebelina (Nodobairdia) triassica Bolz (1971b), later identified as Nodobairdia triassica (Bolz) in Urlichs and Krystyn (2016), as a junior synonym of Nodobairdia mammilata Kollmann (1963). Similarly, we follow KristanTollmann et al. (1980) in re-attributing Triebelina sp. G in Bolz (1971a) to Nodobairdia mammilata Kollmann (1963). Specimens from the Norian-Rhaetian of Romania (Mirăuță et al., 1993) are poorly illustrated and their lateral characters are not observable: here we questionably attribute them to Nodobairdia mammilata Kollmann (1963). Kristan-Tollmann and Hamedani (1973) identified two valves from the late Carnian of Austria as Nodobairdia mammilata without providing the reasons for their doubt on the specific attribution. 
Later, Kristan-Tollmann et al. (1980), followed by KristanTollmann et al. (1991) and Monostori and Tóth (2014), re-attributed these specimens to Nodobairdia mammilata and considered them as very early juveniles with diagnostic ventral longitudinal ridge only suggested by anterior and posterior tiny nodules and two small dorsal nodes hardly visible due to preservation. Here we do not follow this re-attribution for the reasons detailed hereafter. In the smallest specimens attributed to Nodobairdia mammilata (Fig. 3A), those from Sicily (Crasquin et al., 2018) and Hungary (Kristan-Tollmann et al., 1991) already have well-developed dorsal and sub-dorsal nodes. Those from the Northern Calcareous Alps (KristanTollmann and Hamedani, 1973) are of similar dimensions but have a much weaker lateral ornamentation for which elements are hardly distinguished, a fact that can not only be attributed to their preservation state. We consider that the Alpine specimens have been wrongly re-attributed to Nodobairdia mammilata because of their very common juvenile bairdiid contour that is hardly attributable to any precise species. The comparison of their morphology and size with those that may belong to the same ontogenetic stage leads us to formally exclude them from Nodobairdia mammilata.

Nodobairdia mammilata has been documented from the Carnian to the Rhaetian and the dimensions of all specimens from the literature are plotted in Figures $3 \mathrm{~A}$ and $3 \mathrm{~B}$. The dimensions of Carnian and Rhaetian (with "Norian-Rhaetian") specimens are plotted separately in Figure 3A and Figure 3B respectively. The carapace shown in Kristan-Tollmann (1986b) lacks information on magnification or size and is therefore not included. Similarly, Liebermann (1979), Hausmann and Nützel (2015) and Urlichs and Krystyn (2016) did not illustrate any specimen and Kristan-Tollmann (1971) only illustrated the dorsal area of a right valve. The smallest known specimen of Nodobairdia mammilata is a left valve from the middle Carnian of Hungary (Kristan-Tollmann et al., 1991) while the largest ones are LV from the Rhaetian of Iran (Kristan-Tollmann et al., 1980; Kristan-Tollmann, 1988a). Only one complete carapace has been illustrated to date, from the late Carnian of Sicily (Crasquin et al., 2018). Another complete carapace was shown by Kollmann (1963) but it is covered with sediment and the contour of RV is hardly visible so that it is treated as a LV. The size range of Carnian and Rhaetian material indicates the presence of several ontogenetic stages (Figs. 3A and 3B).

During the Carnian (Fig. 3A), LV are more abundant than $\mathrm{RV}$ and a unique complete carapace has been illustrated to date (Crasquin et al., 2018). This carapace shows that the overlap of $\mathrm{LV}$ on RV is only developed along the dorsal and ventral margins and we postulate that LV and RV may roughly plot together in the H/L diagrams throughout the ontogeny. With the additional hypothesis that the largest specimens may be adults, all Carnian specimens of Nodobairdia mammilata are distributed into five scatter plots corresponding to five stages (A-4 to Adult; Fig. 3A). During the Carnian, adults are only known from the Cordevolian of Tyrol (Kristan-Tollmann 1978). Stage A-3 is only represented by a RV from Hungary (Kristan-Tollmann et al., 1991) and the available carapace (Crasquin et al., 2018) corresponds to a stage A-4. The LV from the Lycian Nappes (Plates 1C and 1D) are both A-1 stages and the RV (Plate 1E) may be an A-2 juvenile.

LV are also more abundant than RV during the Rhaetian (Fig. 3B). All dimensions of Nodobairdia mammilata from the literature are distributed into five scatter plots (Figs. 3A and 3B), in line with Bolz (1971b) observation of five ontogenetic stages for Triebelina (Nodobairdia) triassica. Bolz (1971b) added that the ventral ridge is only apparent at the adult stage in Triebelina (Nodobairdia) triassica. The present observations of the entire range of specimens of Nodobairdia mammilata rather indicate that the ventral ridge appears quite early in the ontogeny as it is already clearly expressed on specimens attributed to the A-4 stage (e.g. Crasquin et al., 2018).

Suborder Metacopina Sylvester-Bradley (1961)

Superfamily Healdioidea Harlton (1933)

Family Healdiidae Harlton (1933)

Genus Hungarella Méhes (1911)

Type species. Hungarella problematica Méhes (1911) by original designation.

\section{Hungarella sp.}

(Plate 1F)

Material. One left valve.

Dimensions. $\mathrm{L}=232 \mu \mathrm{m}, \mathrm{H}=164 \mu \mathrm{m}, \mathrm{H} / \mathrm{L}=0.7$.

Occurrences. Sample 328/07, Karapınar Formation, Karadağ Unit, Ağılıovası Yayla section, Lycian Nappes, southwestern Turkey, Cordevolian (Pseudofurnishius murcianus murcianus conodont), early Carnian, Late Triassic (this work).

Remarks. The specimen is very small compared to contemporaneous species (e.g. Urlichs, 1971; Forel et al., 2019 b), which leads us to conclude that it is a rather young juvenile.

Order Myodocopida Sars (1866)

Suborder Myodocopina Sars (1866)

Superfamily Polycopoidea Sars (1866)

Family Polycopidae Sars (1866)

Genus Polycope Sars (1866)

Type species. Polycope orbicularis Sars (1866) by original designation.

Polycope pumicosa schleiferae Kozur in Bunza and Kozur (1971)

(Plates $1 \mathrm{G}$ and $1 \mathrm{H}$ )

1971 Polycope pumicosa schleiferae Kozur in Bunza and Kozur: 14, pl. 2, fig. 17.

2013 Polycopsis n. sp. ex gr. cincinnata (Apostolescu); Moix et al.: pl. 5, fig. 7.

Non 2013 Polycope pumicosa schleferae [sic] Kozur; Monostori and Tóth: 308, pl. 1, fig. 2.

2019a Polycope pumicosa schleiferae Kozur; Forel et al.: 36, fig. 24D.

Material. Two valves.

Dimensions. $\mathrm{L}=234-251 \mu \mathrm{m}, \quad \mathrm{H}=215-220 \mu \mathrm{m}$, $\mathrm{H} / \mathrm{L}=0.88-0.9$ (this material).

Occurrences. Hungary, Cordevolian, early Carnian, Late Triassic (Bunza and Kozur 1971); Tavusçayiri Block, Sorgun Ophiolitic Mélange, Huğlu Tuffite, southern Turkey, Tetraporobrachia haeckeli radiolarian Zone, Julian, middle Carnian, Late Triassic (Forel et al., 2019a); sample 328/07, Karapınar Formation, Karadağ Unit, Ağılıovası Yayla section, Lycian Nappes, southwestern Turkey, Cordevolian (Pseudofurnishius murcianus murcianus conodont), early Carnian, Late Triassic (Moix et al., 2013; this work).

Rejected occurrence. Hungary, Ladinian, Middle Triassic (Monostori and Tóth, 2013).

Remarks. The present specimens have first been discussed by Moix et al. (2013), who attributed them to Polycopsis 
Müller (1894). Polycopsis was erected based on modern material mainly using soft body characters, which led several authors to point out the impossibility to distinguish between Polycope and Polycopsis in the absence of soft parts (e.g. Urlichs, 1972; Neale, 1983). For this reason, Urlichs (1972) chose to re-assign Triassic species to Polycope Sars (1866), and was later followed for instance by Kolar-Jurkovšek (1990) or implicitly by Monostori and Tóth (2013), Sebe et al. (2013) and Forel et al. (2019a). We are in line with Urlichs (1972) and subsequent authors in considering that records of Polycopsis in the Triassic are unreliable and that Polycopsis species in Kozur (1970), Bunza and Kozur (1971), Kozur et al. (2000) should be re-assigned to Polycope.

Specimens attributed to Polycope pumicosa schleiferae from the Ladinian, Middle Triassic, of Hungary (Monostori and Tóth, 2013) are here excluded from this species because the illustrated specimen (Pl. 1, fig. 2 in Monostori and Tóth, 2013) is rostrate anteriorly and lacks the diagnostic narrow ridge along the free margin. The dimension range of this material is also larger than that of the type material (a diameter ranging from 800 to $860 \mu \mathrm{m}$; type material ranging from 274 to $297 \mu \mathrm{m}$ in length and from 250 to $270 \mu \mathrm{m}$ in height, Bunza and Kozur (1971)) but this feature is not discriminant enough as it may relate to ontogeny. Monostori and Tóth (2013) also re-attributed Polycope cf. pumicosa schleiferae from the early Anisian, Middle Triassic, of Romania (Crasquin and Grădinaru, 1996, later reported from the same area by Sebe et al., 2013) to Polycope pumicosa schleiferae. However, this taxonomic choice was not discussed. Here we do not subscribe to this re-attribution as the material from the Dobrogea has smaller reticulations dominated ventrally by a series of concentric ridges parallel to the ventral margin and lacks the narrow ridge along free margin. Consequently, Polycope pumicosa schleiferae is here considered as restricted to the Carnian and has been reported from Hungary (Bunza and Kozur (1971)) and Turkey (Forel et al., 2019a; this work). The precise age of the type material of Polycope pumicosa schleiferae is problematic as it is only attributed to the early Carnian (Unterkarn) from Bakonyszücs in Hungary (p. 14 in Bunza and Kozur (1971)), with no further information. Bunza and Kozur (1971) subscribe to the three-fold subdivision of the Carnian but in the absence of precise elements or information to discuss this age attribution, the Hungarian occurrence of Polycope pumicosa schleiferae is questionably attributed to the Cordevolian.

Morphologically, it is worth noting that the valve shown in Plate $1 \mathrm{H}$ displays rows of small pores arranged parallel to each reticula wall, which were never observed previously.

\section{Results and discussion}

\subsection{Diversity and palaeoenvironment}

All specimens obtained from the Cordevolian, early Carnian of the Karapınar Formation in the Lycian Nappes (southwestern Turkey), are isolated valves, implying that they may not be autochthonous (e.g. Oertli, 1971; Boomer et al., 2003). The small dimensions of the material seem to reinforce this hypothesis, as detailed in the systematic palaeontology chapter of this contribution: Hungarella sp. and all Bairdiidae of this study are interpreted as juveniles and Polycope pumicosa schleiferae is only slightly smaller than the type material. It is therefore quite difficult to build strong palaeoenvironmental interpretations because of the scarceness of the material and of its possible allochthonous origin but some elements are nevertheless significant.

Nodobairdia mammilata and Mirabairdia longispinosa are subtidal species that have been previously recorded from lagoonal/restricted shallow subtidal (Liebermann, 1979) to basinal settings during the Carnian (Nodobairdia mammilata: Hausmann and Nützel (2015); Mirabairdia longispinosa: Kristan-Tollmann (1978)). Bunza and Kozur (1971) did not provide information on the environmental preferences of Polycope pumicosa schleiferae, but it has been reported from contemporaneous offshore areas (Forel et al., 2019a). This species, previously identified as Polycopsis n. sp. ex gr. cincinnata (Apostolescu) [referring to Apostolescu (1959)] in Moix et al. (2013), has been reported as occurring in "moderately deep water below the storm wave base and in deep water" (p. 419 in Moix et al., 2013). However, it is not clear on which data or references this assertion relies. Nevertheless, the absence of typical deep-water taxa such as those from the Julian of the Mersin Mélange (Turkey; Forel et al., 2019a) and the characteristics of the three species detailed above, point to a relatively offshore subtidal palaeoenvironment under moderate water depth. Moix et al. (2013, p. 419) add that "the presence of several typical sculptured Bairdiidae without disintegration of the nodes and ribs indicates that the water depth was around $100 \mathrm{~m}$, estimating warm water in a water depth at 70 to $100 \mathrm{~m}$ or not much deeper". This sentence is problematic because:

- No details of the occurring Bairdiidae are provided;

- The only specimen figured in Moix et al. (2013, here re-identified as Mirabairdia sp.) lacks nodes or ribs;

- These explanations are themselves problematic as ribs and nodes are most of the time relatively low-lying ornamental features so that this deduction should be used for spines rather than ribs and nodes.

\subsection{On the palaeobiogeographical distribution of ostracods during the Carnian}

\subsubsection{Mesozoic Neotethys}

The conodont Pseudofurnishius murcianus murcianus van den Boogaard (1966), retrieved from the studied sample, is a typical indicator for the Neotethyan domain and shows that the Karadağ Unit belongs to the Cimmerian Taurus terrane and was part of the northern passive margin of the Neotethys (Fig. 4; Moix et al., 2013).

The Palaeotethys existed between Eurasia and Gondwana in the Late Palaeozoic and was subducted northwards during the Middle-Late Triassic (e.g. Robertson and Dixon, 1984, Dercourt et al., 1986, 1993, 2000; Moix et al., 2008). Its closure triggered the opening of the Neotethys by the rifting of continental fragments (Taurides, Cimmerian blocks) from the northern margin of the Gondwana. In parallel, the northward subduction of the Palaeotethys beneath Eurasia opened up a series of back-arc basins along the southern area of Eurasia (Fig. 4). The closure of the Palaeotethys was terminated by the collision of the Taurides and Eurasia in the latest Triassic, known as the Cimmerian orogenic event. In the mean time, the Neotethys was opening to the south.

The geodynamic evolution of the Neotethys during the Mesozoic is currently described by two main models. The first 


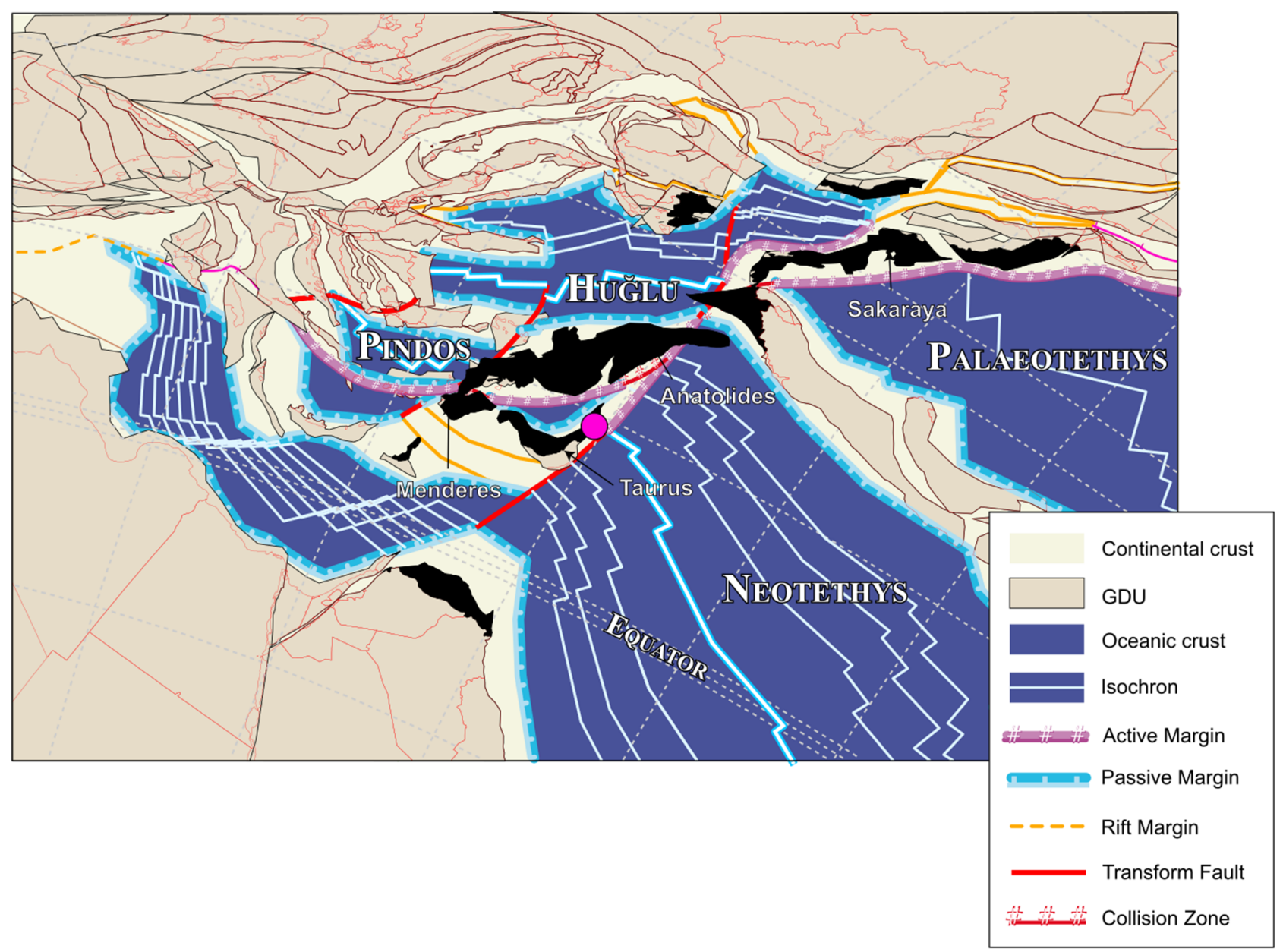

Fig. 4. Palaeogeographic map of the western Tethyan area for the Late Triassic (230 Ma). In black are the dispersed parts of Turkey (modified from Moix et al., 2013). The pink circle indicates the position of the studied area.

model, termed "one-ocean thesis", was introduced by Bernoulli and Laubscher (1972) and later reworked by Neubauer and von Raumer (1993), Schmid et al. (2008) and Bortolotti et al. (2013). The second one proposes multiple oceanic basins and microcontinents (e.g. Sengör, 1984; Robertson and Dixon, 1984; Stampfli and Borel, 2004; Stampfli and Kozur, 2006; Moix et al., 2008; Robertson et al., 2009, 2013). A relatively simple one-ocean model has been proposed for the Alpine-Dinaric-Hellenic belt, but comparisons with Eastern Mediterranean and Middle East led to more complicated scenarios (e.g. Robertson et al., 2009). The close similarity of the upper Julian-lower Tuvalian radiolarian faunas from the Northern Calcareous Alps through the Lagonegro Basin, Sicily, Greece and farther east in the Antalya nappes, in the Mersin Mélange and in Elbistan (Turkey) may confirm the idea of a single oceanic basin (Ozsvárt et al., 2017).

\subsubsection{Origin and palaeobiogeography of ostracods during the Triassic: state of the art}

The area of origin of Mesozoic tethyan ostracods has been considered by three main schools of thoughts:

- The "western America" hypothesis, which considers that they radiated in western America, particularly in British
Columbia, with a subsequent westward trans-panthalassic dispersion (Kristan-Tollmann and Tollmann, 1981, 1982; Kristan-Tollmann, 1986a, b, 1988a);

- The "western Tethys" hypothesis that has for instance been proposed for Polycope cincinnata Apostolescu (1959) that occurs in the western Tethys during the Middle and Late Triassic and became cosmopolitan, reaching Timor, in the Early Jurassic (Lord, 1988). Bate (1977) considered that the European Province may have been the radiation place of the majority of important Mesozoic families;

- The "eastern Tethys" hypothesis that has been proposed for several taxa such as the vallate healdiid Hermiella (Kristan-Tollmann, 1993), cytheroids (Bate, 1977; Lord, 1988 based on Kristan-Tollmann, 1983) or ornate bairdiids (Ketmuangmoon et al., 2018; discussed below). Lord (1988) hypothesized that typical Jurassic taxa might have originated on the eastern side of the Tethys, migrated to the western Tethys during the Late Triassic transgression and diversified there up to the known Jurassic record. Recently, it has been proposed that Carinobairdia and Schulerideidae may have radiated on the Chinese coasts during the Tuvalian, late Carnian, and migrated westward later during the Late Triassic (Forel et al., 2019b). At the generic level, this Chinese record also represents the oldest known 
occurrence of Carinobairdia that may thus have colonized western tethyan areas through the Carinobairdia cabralaeCarinobairdia alpina lineage.

The knowledge of the origin of Mesozoic marine ostracods and their diffusion ways is still heterogeneous. For Early Jurassic ostracods, five provinces have been recognized (European, Tethyan, North African, American, East African; Bate, 1977) as well as important changes in their provincialism (Arias, 2007). The Early Jurassic provincialism has been related to the spread of cosmopolitan species, extinction of endemic species, disappearance of geographical barriers, warmer climate conditions and rising sea level (Arias and Whatley, 2009).

The palaeobiogeographical distribution of ostracods during the Triassic has been discussed mainly during the 70's and 80's, but was never really reconsidered since this relatively prolific period. In 1973, Kozur (1973b) distinguished three distinct conodonts and ostracods provinces during the Triassic: southern boreal, tethyan (subdivided into nevadian, asiatic, dinarian, austroalpine, westmediterranean and german subprovinces) and northern boreal provinces. Kozur (1973b) also proposed successive faunal connexions within the tethyan province, which might have been connected to the northern boreal province through the german subprovince during the Early Triassic. A westward migration of brackish water and euryhaline ostracods in the Middle Triassic (upper Illyrian-Ladinian) is finally proposed from the asiatic subprovince through the eastern Carpathians and northern margin of the Black Sea. Later, Kristan-Tollmann and Tollmann (1981, 1982) and KristanTollmann (1986a, 1988a, b, 1991) analysed the distribution of diverse fossil groups (algae, crinoids, foraminifers, holothurians, anomuran coprolites, halobiids, brachiopods, ammonoids and ostracods) concluded that it was homogeneous within the Tethys during the Late Triassic. On the opposite, six provinces have been identified for foraminifer species in the Late Triassic (Chablais et al., 2011): the peri-Tethys, eastern Gondwana, eastern Laurasia, central Pacific, Sambosan and other seamounts. However, no evident palaeobiogeographic restrictions is observed at the generic level. More recently, Chen et al. (2016) proposed the existence of two distinct provinces for conodonts during the Middle and Late Triassic, viz. tethyan and panthalassan domains. These diverse views are relatively challenged by recent works that rather document an increasing differentiation occurred between the Neotethyan and the Palaeotethyan faunas, with a maximum in the Cordevolian (e.g. Moix et al., 2007). During this interval, the conodont, ostracod, holothurian sclerite and sponge spicule faunas show that the Apulian-Tauride High clearly separated (e.g. Kozur, 2000; Stampfli and Kozur, 2006; Moix et al., 2007, 2013; Fig. 4):

- The Neotethyan fauna to the south, for instance marked by Pseudofurnishius murcianus van den Boogaard (1966) and Theelia tubercula Kristan-Tollmann (1963);

- The northern Tethyan fauna in the Huğlu-Pindos Ocean and its shelves (including the Antalya Nappes), to the north.

After the breakup of the Apulian-Tauride High that may have occurred in the Julian, the faunas of the Neotethys and these of the Tethyan areas (Palaeotethyan back-arcs) immediately north of the Tauric Autochthon became almost identical (Kozur, 2000; Moix et al., 2007).
Since these early works, this major issue has not been further discussed in details. The present work, following Forel et al. (2019b), aims at characterizing migration patterns underlying the observed Late Triassic tethyan homogeneity.

\subsubsection{The Lycian Nappes record}

Of the five species we document from the Lycian Nappes, three are known from other Triassic marine successions: Mirabairdia longispinosa Kristan-Tollmann, Nodobairdia mammilata Kollmann and Polycope pumicosa schleiferae Kozur. Their Cordovelian occurrences in the Lycian Nappes revive the discussion on palaeogeographical distribution during the Late Triassic, homogeneity of tethyan communities, dispersal routes as well as radiation areas. In this discussion, we considered as a necessary condition to be able to verify and confirm the conspecificity of all specimens attributed to the studied species. For this reason, articles that record but not illustrate the species are here excluded as they may introduce artificial occurrences. Therefore, the following references are omitted from this discussion:

- Liebermann (1979; Cordevolian, early Carnian, Italy): Mirabairdia longispinosa;

- Liebermann (1979; Cordevolian, early Carnian, Italy) and Hausmann and Nützel (2015; Carnian, Italy): Nodobairdia mammilata.

The updated palaeogeographical distribution of the three species through time is summarized in Table 2. Polycope pumicosa schleiferae and Mirabairdia longispinosa are both restricted to the Carnian of the western Tethys sensu lato. In the present state of our knowledge, Polycope pumicosa schleiferae is known from the early and middle Carnian and does not extend in the late Carnian. During the Cordevolian, it occurs on the northern portion of the Neotethys (Moix et al., 2013; this work) and possibly on the northern margin of the Huğlu Basin (Hungary; Bunza and Kozur (1971)). During the middle Carnian, it is only known from the southern margin of the Huğlu Basin (Turkey; Forel et al., 2019a). Mirabairdia longispinosa is known from the early and late Carnian (Tab. 2), possibly illustrating the lack of data for the middle Carnian. During the Cordevolian, Mirabairdia longispinosa occurs on the northern margin of the Huğlu Basin (Kollmann (1963); Kristan-Tollmann, 1971, 1978; Zorn, 2010) and in the Neotethys (this work). It is last documented in the late Carnian on the southern margin of the Huğlu Basin (Forel et al., 2018).

Nodobairdia mammilata has a longer history, ranging from the early Carnian to the Rhaetian (Tab. 2). Until the present record, this species was restricted to the Alpine area during its entire Carnian history (Kristan-Tollmann, 1971, 1978; Kollmann (1963); Zorn, 2010; Kristan-Tollmann et al., 1991; Monostori, 1994; Kristan-Tollmann and Hamedani, 1973). Occurrences in Sicily during the late Carnian (Crasquin et al., 2018) and in Australia later during the Norian (KristanTollmann, 1986b) and upper Norian-Rhaetian (Dépêche and Crasquin, 1992; Crasquin and Dépêche, 1993) could have witnessed a large diffusion of Nodobairdia mammilata in the Neotethys after the Carnian. However, the present report indicates that Nodobairdia mammilata was already present in the Huğlu Basin and on the northern area of the Neotethys 
Table 2. Stratigraphical and palaeogeographical ranges of ostracod species recorded outside the Lycian Nappes during the Triassic; stages durations not to scale. Light grey squares: literature-based distribution; dark grey squares: new distribution from the Lycian Nappes.

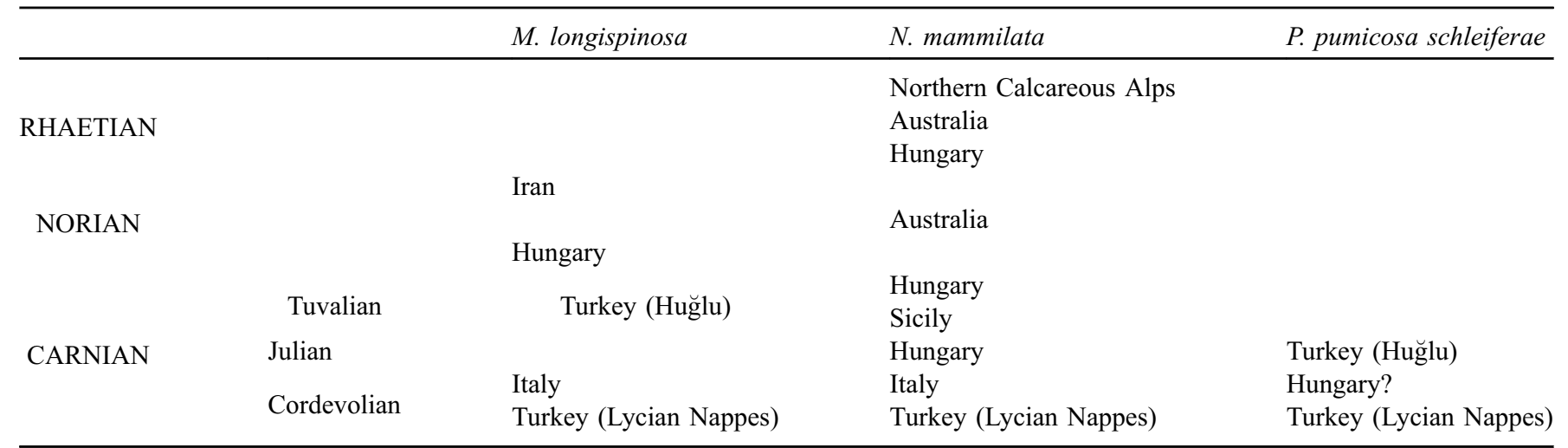

Abbreviations: A: Austria; C: China; G: Germany; H: Hungary; I: Iran; R: Romania; S: Slovakia; T: Turkey; Ti: Tibet.

Ocean in the Cordevolian, at the base of the Carnian. Consequently, Polycope pumicosa schleiferae, Mirabairdia longispinosa and Nodobairdia mammilata were already largely distributed during the Cordevolian, early Carnian, implying that they may have radiated earlier, possibly at the end of the Ladinian. Although data are still lacking to propose a robust hypothesis on the radiation areas of these species, it is reasonable to consider their early evolutive history as purely western-tethyan. Only a larger geographical coverage of the Middle-Late Triassic transition will clarify whether they radiated in neotethyan or palaeotethyan waters. As described earlier, the disaggregation of the Apulian-Tauride High that separated neotethyan and palaeotethyan faunas is traditionally placed in the Julian, Middle Carnian (e.g. Kozur, 2000; Stampfli and Kozur, 2006; Moix et al., 2007, 2008, 2013). Yet, the ostracod record indicates that communication ways were already present and provided stable palaeoenvironmental conditions for these benthic organisms to spread from one ocean to the other at the base of the Cordevolian.

During the Late Triassic, the Cimmerian continent, the width of which is still unknown, was crossed by major faults (Fig. 4) that could have served for faunal exchanges between the Palaeotethys and Neotethys during the collision phase. The migrating flexural bulge and development of a foreland basin demonstrate that the Tauric-Anatolian and Beydağları-Apulian domains were separated at least by a few hundred kilometers, this separation being placed in the Julian (e.g. Kozur, 2000; Moix et al., 2008). These flexural structures may have been relatively deep corridors allowing faunal relations as early as in the Cordevolian as shown by the ostracods reported here. At some places and before it was completly overlapped by the accretionary prism, the Cimmerian block may have been brought at already important depth to allow faunal exchanges before the closure of the Palaeotethys (Fig. 5). We propose here that the opening of the communication between the Palaeotethys and the Neotethys may have initiated already during the Cordevolian, and became more widely established during the Julian for more intense, and therefore more visible, faunal exchanges (pers. comm. Prof. Dr. Gérard Stampfli, Université de Lausanne).

Following these observations and interpretations, it is necessary to confront the idea of homogeneity of tethyan

\section{CORDEVOLIAN}

SW

NE

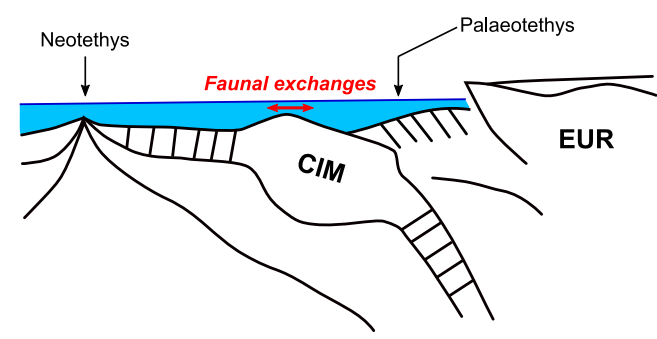

PRE-CORDEVOLIAN

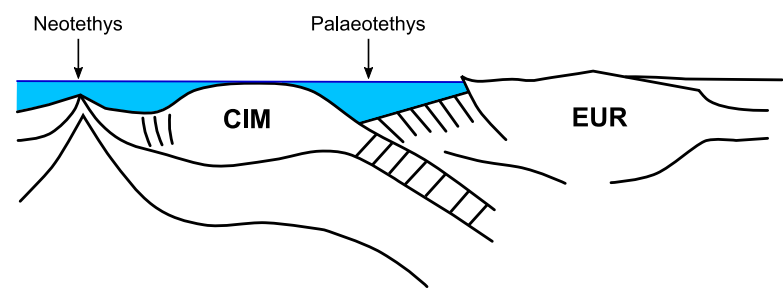

Fig. 5. Sketch illustrating the successive pre-Cordevolian (bottom) and Cordevolian (top) position of the Cimmerian block allowing for faunal exchanges only from the Cordevolian onwards. CIM: Cimmerian block. EUR: Europe.

ostracods during the Late Triassic (e.g. Kristan-Tollmann and Tollmann, 1981, 1982; Kristan-Tollmann, 1986a, 1988a, b, 1991) with that of the opening of Neotethys and Palaeotethys communication during the Cordevolian. These two conceptions of Late Triassic ostracod faunas may seem antithetical but they need to be replaced in a stratigraphical context to get insight into the temporal dynamism of ostracods distribution. The synthesis on the homogeneity of tethyan marine communities of Kristan-Tollmann (1988a) offered a static summary of the large-scale distribution of diverse algae, crinoid, holothurian, ostracod and anomouran coprolite species from the Middle Triassic (Late Ladinian, down to Late Anisian for ostracods) to the end of the Late Triassic (Rhaetian). Nodobairdia mammilata is part of the typical tethyan taxa that 
led Kristan-Tollmann (1988a) to conclude to the relative homogeneity of the tethyan communities during the Late Triassic. The present record is in line with this observation in showing a large distribution of this species during the Cordevolian. As detailed above, several hypotheses were brought for the geographical trend of tethyan colonization but none was replaced in a temporal context. It is only later that temporalization was brought with the proposal of uniformization of palaeotethyan and neotethyan faunas during the Julian (e.g. Kozur, 2000; Stampfli and Kozur, 2006; Moix et al., $2007,2008,2013)$. Here, the initiation of this uniformity is placed in the Cordevolian. The homogeneization of the ostracod faunas reported by several authors during the Late Triassic (e.g. Kristan-Tollmann and Tollmann, 1981, 1982; Kristan-Tollmann, 1986a, 1988a, b, 1991) might therefore relate to the opening of communications between the Neotethys and the Palaeotethys oceans during the Cordevolian, early Carnian. However, Kristan-Tollmann (1988a) states that the uniformity was already recognizable at the end of the Ladinian, and even at the end of the Anisian for ostracods. This early uniformity needs to be carefully re-considered as it cannot be explained by the same tectonic event and may correspond to different diversity dynamics.

\subsubsection{Generic versus specific palaeogeographical patterns}

The purely western-tethyan history of Polycope pumicosa schleiferae, Mirabairdia longispinosa and Nodobairdia mammilata and the opening of the oceanic communication reactivate the discussion on the origin of tethyan ostracods and on their palaeogeographical homogeneity during the Late Triassic (e.g. Kristan-Tollmann and Tollmann, 1981, 1982; Kristan-Tollmann, 1986a, 1988a; Lord, 1988; Forel et al., $2019 b$ ). The distribution pathways are also important to discuss as they may provide insights into the history of radiation, colonization events and associated environmental conditions.

The oldest occurrences of Nodobairdia are from the Anisian lato sensu of the Suhkothai terrane (Ketmuangmoon et al., 2018) and late Anisian of South China (KristanTollmann, 1983). It is known up to the Rhaetian (Bolz, 1971a, b; Kristan-Tollmann et al., 1979, 1980, Kristan-Tollmann, 1988a; Dépêche and Crasquin, 1992; Crasquin and Dépêche, 1993; Mette et al., 2012; Monostori and Tóth, 2014). These palaeogeographical and stratigraphical ranges led Ketmuangmoon et al. (2018) to propose that Southeast Asia may have been an important area of generic origination during the Middle Triassic, with Nodobairdia later spreading to the entire tethyan areas. This observation was recently extended to Carinobairdia (Forel et al., 2019b). When considering the species distribution, Nodobairdia mammilata colonized most of the western Tethys to Iran but it apparently did not extend to the easternmost areas.

The history of Mirabairdia drastically differs from that of Carinobairdia and Nodobairdia. Its first attested occurrence is of Capitanian age, Middle Permian, in South China (Zazzali et al., 2015). During its entire Permian history, Mirabairdia has been restricted to South China, with a maximum of diversity during the Changhsingian, Late Permian (e.g. Shi and
Chen, 1987, 2002; Hao, 1994, 1996; Yi, 2004; Yuan et al., 2009; Crasquin et al., 2010). During the Triassic, a westward trend similar to that reported for Nodobairdia is documented for Mirabairdia, with records in South China during the Anisian (Kristan-Tollmann, 1983) and all around the Huğlu Basin during the Middle and Late Triassic: Turkey (Julian, middle Carnian, Forel et al., 2019a; Tuvalian, late Carnian, Forel et al., 2018), Italy (Julian, middle Carnian, Kollmann (1963); Liebermann, 1979; Cordevolian, early Carnian, Kristan-Tollmann (1978)), Hungary (Anisian, Middle Triassic, Kozur, 1971), Austria (Julian, middle Carnian, Kollmann (1963); Rhaetian, Kozur, 1973a; Anisian, Middle Triassic, Mette et al., 2014). This record may imply a westward migration along the northern margin of the Palaeotethys up to the Anisian. It may have been followed by the colonization of the Huğlu Basin during the Carnian with an extension to the north of the Neotethys at the very beginning of the Carnian as shown by the present record of the Cordevolian of the Lycian Nappes. The history of the genus Mirabairdia therefore implies much older roots than for Carinobairdia and Nodobairdia and survival to the end-Permian extinction. However, the present contribution provides the first known record of Mirabairdia in the Neotethys.

This mixture of endemism between generic and specific levels has also been reported during the Late Triassic for foraminifers (Chablais et al., 2011). These distinct generic and specific patterns show that these problematics need to be studied in their full complexity. It is interesting to note that generic patterns rather show a westward trend for all these taxa.

\section{Conclusions}

Ostracods of Cordevolian, early Carnian, Late Triassic, age have been retrieved from the Karapınar Formation cropping out at the Ağllovası Yayla section, located in the Lycian Nappes in southwestern Turkey. Five species are found, including three typical Late Triassic species: Mirabairdia longispinosa Kristan-Tollmann (1978), Nodobairdia mammilata Kollmann (1963) and Polycope pumicosa schleiferae Kozur in Bunza and Kozur (1971). We discuss the taxonomy of the species recovered, describe the ontogeny of Nodobairdia mammilata and observe five stages for the Carnian and Rhaetian material. We discuss the palaeoenvironmental implications of the assemblage, pointing toward a deposition in the relatively offshore subtidal zone under moderate water depth. We finally discuss the palaeobiogeographical distribution of marine ostracods during the Late Triassic: it implies that communications between the Neotethys and the Huğlu Basin might have been already open during the Cordevolian.

\section{Abbreviations}

$\begin{array}{ll}\text { RV } & \text { Right valve } \\ \text { LV } & \text { Left valve } \\ \text { DB } & \text { Dorsal border } \\ \text { AD } & \text { Bantero-dorsal border } \\ \text { PDB } & \text { Postero-dorsal border } \\ \text { H } & \text { Height } \\ \text { L } & \text { Length }\end{array}$


Acknowledgments. We are very grateful to Prof. Dr. Gérard Stampfli (Université de Lausanne) for stimulating discussion and clarification on tectonic features related to the opening of the Neotethys and Palaeotethys communication. Two anonymous reviewers and the editors are thanked for their constructive comments and corrections.

\section{References}

Apostolescu V. 1959. Ostracodes du Lias du Bassin de Paris. Revue de l'Institut Français du Pétrole 14(6): 795-817.

Arias C. 2007. Changes in ostracod provincialism during the Early Toarcian in the European Epicontinental Sea-Western Tethys area. Revista española de micropaleontología 38: 245-267.

Arias C, Whatley RC. 2009. Multivariate hierarchical analyses of Early Jurassic Ostracoda assemblages. Lethaia 42: 495-510.

Bate RH. 1977. Jurassic Ostracoda of the Atlantic Basin. In: Swain FM, ed. Stratigraphic micropaleontology of Atlantic basin and borderlands. New York: Elsevier Scientific Pub. Co. Amsterdam, pp. 231-244.

Benton MJ, Zhang QY, Hu SX, et al. 2013. Exceptional vertebrate biotas from the Triassic of China, and the expansion of marine ecosystems after the Permo-Triassic mass extinction. EarthScience Reviews 125: 199-243.

Bernoulli D, Laubscher H. 1972. The palinspastic problem of the Hellenides. Eclogae Geologicae Helvetiae 65: 107-118.

Bernoulli D, de Graciansky PC, Monod O. 1974. The extension of the Lycian Nappes (SW Turkey) into the southeastern Aegean Islands. Eclogae Geologicae Helvetiae 67: 39-90.

Bolz H. 1971a. Late Triassic Bairdiidae and Healdiidae. In: Oertli HJ, ed. Paléoécologie des Ostracodes. Bulletin du Centre de Recherche SNPA 5 (Supplement), pp. 717-745.

Bolz H. 1971b. Die Zlambach-Schichten (alpine Obertrias) unter besonderer Berück- sichtigung der Ostrakoden, 1: Ostrakoden der Zlambach-Schichten, besonders Bairdiidae. Senckenbergiana Lethaea 52: 129-283.

Boomer I, Horne DJ, Slipper IJ. 2003. The use of ostracods in palaeoenvironmental studies or what can you do with an Ostracod shell? Palaeontological Society Papers 9: 153-179.

Bortolotti V, Chiari M, Marroni M, Pandolfi L, Principi G, Saccani E. 2013. Geodynamic evolution of ophiolites from Albania and Greece (Dinaric-Hellenic belt): one, two, or more oceanic basins? International Journal of Earth Sciences 102: 783-811.

Brandão SN, Hoppema M, Kamenev GM, et al. 2019. Review of Ostracoda (Crustacea) living below the Carbonate Compensation Depth and the deepest record of a calcified ostracod. Progress in Oceanography 178, in press. https://doi.org/10.1016/j. pocean.2019.102144.

Brunn JH, Dumont JF, de Graciansky PC, et al. 1971. Outline of the geology of the Western Taurides. In: Campbell AS, ed. Geology and history of Turkey. Tripoli, Libya: Petroleum Exploration Society of Libya, pp. 225-255.

Brusatte SL, Benton MJ, Lloyd GT, Ruta M, Wang SC. 2011. Macroevolutionary patterns in the evolutionary radiation of archosaurs (Tetrapoda: Diapsida). Earth and Environmental Science Transactions of the Royal Society of Edinburgh 101: 367-382.

Buffetaut E, Martin M, Monod O. 1988. Phytosaur remains from the Çenger Formation of the Lycian Taurus (western Turkey); stratigraphical implications. Geobios 21: 237-243.

Bunza G, Kozur H. 1971. Beiträge zur Ostracodenfauna der tethyalen Trias. Geologisch-Paläontologische Mitteilungen Innsbruck 1: $1-76$.
Chablais J, Martini R, Kobayashi F, Stampfli GM, Onoue T. 2011. Upper Triassic foraminifers from Panthalassan carbonate buildups of Southwestern Japan and their paleobiogeographic implications. Micropaleontology 57(2): 93-124.

Chen ZQ, Benton MJ. 2012. The timing and pattern of biotic recovery following the end-Permian mass extinction. Nature Geoscience 5: 375-383.

Chen YL, Krystyn L, Orchard MJ, Lai XL, Richoz S. 2016. A review of the evolution, biostratigraphy, provincialism and diversity of Middle and early Late Triassic conodonts. Papers in Palaeontology 2(2): 235-263.

Crasquin-Soleau S, Dépêche F. 1993. Paleoecology of ODP LEG 122 Triassic Ostracodes (Wombat Plateau, NW Australia). Geobios 26 (3): 331-344.

Crasquin S, Forel MB. 2015. Ostracods (Crustacea) through PermianTriassic events. Earth-Science Reviews 137: 52-64.

Crasquin-Soleau S, Grădinaru E. 1996. Early Anisian ostracode fauna from the Tulcea unit (Cimmerian North Dobrogean orogeny, Romania). Annales de Paléontologie 82: 59-116.

Crasquin-Soleau S, Galfetti T, Bucher H, Kershaw S, Feng QL. 2007. Ostracod fauna recovery in the aftermath of Permian-Triassic crisis: dating of the Palaeozoic- Mesozoic turnover. Hydrobiologia 585: 13-27.

Crasquin S, Forel MB, Feng QL, Yuan AH, Baudin F, Collin PY. 2010. Ostracods (Crustacea) through Permian-Triassic boundary in South China: the Meishan stratotype (Zhejiang Province). Journal of Systematic Palaeontology 8: 331-370.

Crasquin S, Scuito F, Reitano A. 2018. Late Carnian (Tuvalian, Tropites dilleri zone) ostracods (Crustacea) from the Mufara Formation (Monte Scalpello, Central-Eastern Sicily, Italy). Annales de Paléontologie 104(2): 129-142.

Dépêche F, Crasquin-Soleau S. 1992. 26. Triassic marine ostracodes of the Australian margin (Holes 759B, 760B, 761C, 764A and 764B). Proceedings of the Ocean Drilling Program, Scientific Results 122: 453-462.

Dercourt J, Zonenshain LP, Ricou LE, et al. 1986. Geological evolution of the Tethys belt from the Atlantic to the Pamirs since the Lias. Tectonophysics 123: 241-315.

Dercourt J, Ricou LE, Vrielynck B. 1993. Atlas Tethys palaeoenvironmental maps. Paris: Gauthier-Villars.

Dercourt J, Gaetani M, Vrielynck B, et al. 2000. Peri-Tethys Palaeogeographical Atlas. Paris: Gauthier-Villars.

Forel MB, Ozsvárt P, Moix P. 2018. Carnian (Late Triassic) ostracods from the Sorgun Ophiolitic Mélange (Southern Turkey): Taxonomy, palaeoenvironment and evidence of predation. Palaeontologia Electronica 21.2.26A: 1-23.

Forel MB, Tekin UK, Okuyucu C, Bedi Y, Tuncer A, Crasquin S. 2019a. Discovery of a long-term refuge for ostracods (Crustacea) after the end-Permian extinction: A unique Carnian (Late Triassic) fauna from the Mersin Mélange, southern Turkey. Journal of Systematic Palaeontology 17: 9-58.

Forel MB, Thuy B, Wisshak M. 2019b. Digging into the ancestral stocks of Jurassic lineages: ostracods (Crustacea) from Carnian (Late Triassic) sponge mounds from the Maantang Formation (South China). Bulletin de la Société Géologique de France 190(9): 1-29.

Graciansky de PC. 1968. Stratigraphie des unités superposées dans le Taurus Lycien et place dans l'arc dinaro-taurique. Bulletin of the Mineral Research and Exploration Institute of Turkey 71: 29-41.

Graciansky de PC. 1972. Recherches géologiques dans le Taurus Lycien. Thèse de doctorat, Université Paris Sud-Centre d'Orsay, Paris, $762 \mathrm{p}$.

Hao W. 1994. The development of the Late Permian-Early Triassic ostracod fauna in Guizhou Province. Geological Review 40(1): 87-93 [In Chinese with English abstract]. 
Hao W. 1996. Ostracods from the Upper Permian and Lower Triassic of the Zhenfeng section, South China. Journal of Geosciences, Osaka City University 39(2): 19-27 [In Chinese with English abstract].

Harloff J. 1993. Ostracoden des Unter-Pliensbachiums in BadenWürttemberg. Stuttgarter Beiträge zur Naturkunde Serie B. Geologie und Paläontologie 191: 1-214.

Harlton BH. 1933. Micropaleontology of the Pennsylvanian Johns Valley Shale of Ouachita Mountains, Oklahoma and its relationships to the Mississippian Caney Shale. Journal of Paleontology 7: 3-29.

Hausmann IM, Nützel A. 2015. Diversity and palaeoecology of a highly diverse Late Triassic marine biota from the Cassian Formation of north Italy. Lethaia 48: 235-255.

Hillebrandt AV, Krystyn L, Kürschner WM. 2007. A candidate GSSP for the base of the Jurassic in the Northern Calcareous Alps (Kuhjoch section, Karwendel Mountains, Tyrol, Austria). ISJS Newsletter 34(1): 2-20.

Hillebrandt AV, Krystyn L, Kürschner WM, et al. 2013. The Global Stratotype Sections and Point (GSSP) for the base of the Jurassic System at Kuhjoch (Karwendel Mountains, Northern Calcareous Alps, Tyrol, Austria). Episodes 36(3): 162-198.

Horne DJ, Cohen A, Martens K. 2002. Taxonomy, morphology and biology of Quaternary and living Ostracoda. In: Holmes JA, Chivas A, eds. The Ostracoda: applications in Quaternary Research. Geophysical Monograph. Washington, DC: American Geophysical Union, pp. 5-36.

Karanovic I. 2012. Recent freshwater ostracods of the world. Berlin, Heidelberg: Springer, 605 .

Ketmuangmoon P, Chitnarin A, Forel MB, Tepnarong P. 2018. Diversity and paleoenvironmental significance of Middle Triassic ostracods (Crustacea) from northern Thailand: Pha Kan Formation (Anisian, Lampang Group). Revue de micropaléontologie 61(1): 3-22.

Klompmaker AA, Nützel A, Kaim A. 2016. Drill hole convergence and a quantitative analysis of drill holes in mollusks and brachiopods from the Triassic of Italy and Poland. Palaeogeography, Palaeoclimatology, Palaeoecology 457: 342-359.

Kolar-Jurkovšek T. 1990. New ostracod and conodont species from the Triassic strata of Slovenia (NW Yugoslavia). Geologija 31-32: 219-224.

Kollmann K. 1960. Ostracoden aus der alpinen Trias. I Parabairdia n. g. und Ptychobairdia n. g. (Bairdiidae). Jahrbuch der Geologischen Bundesanstalt 5: 79-105.

Kollmann K. 1963. Ostracoden aus der alpinen Trias II. Weitere Bairdiidae. Jahrbuch der Geologischen Bundesanstalt 106: 121203.

Kozur H. 1970. Neue Ostracoden-Arten aus dem obersten Anis des Bakonyhochlandes (Ungarn). Berichte Naturwiss, Vereins Innsbruck 58: 384-428.

Kozur H. 1971. Die Bairdiacea der Trias. Teil 1: Skulpturierte Bairdiidae aus Mitteltriassischen Flachwasser. Geologisch Paläontologische Mitteilungen Innsbruck 1: 1-27.

Kozur H. 1973a. Beiträge zur Stratigraphie und Paläontologie der Trias. Geologisch-Paläontologische Mitteilungen Innsbruck 3(1): $1-30$.

Kozur H. 1973b. Faunenprovinzen in der Trias und ihre Bedeutung für die Klärung der Paläogeographie. Geologisch-Paläontologische Mitteilungen Innsbruck 3(8): 1-41.

Kozur H. 2000. Northern origin of the Antalya and Alanya Nappes (Western Taurus, Turkey) and causes for the end of the Tethyan faunal provincialism during the middle Carnian. In: Vlahovic I, Biondic R, eds. 2nd Croatian Geological Congress, Zbornik radova, Zagreb, pp. 275-282.
Kozur H. 2003. Integrated ammonoid, conodont and radiolarian zonation of the Triassic and some remarks to Stage/Substage subdivision and the numeric age of the Triassic stages. Albertiana 28: 57-74.

Kozur H, Mostler H. 1994. Anisian to Middle Carnian Radiolarian zonation and description of some stratigraphically important Radiolarians. Geologisch-Paläontologische Mitteilungen Innsbruck 3: 39-255.

Kozur H, Mostler H. 1996. Longobardian (Late Ladinian), Oertlispongidae (Radiolaria) from the Republic of BosniaHercegovina and the stratigraphic value of advanced Oertispongidae. Geologisch-Paläontologische Mitteilungen Innsbruck 4: 105193.

Kozur H, Senel M, Tekin UK. 1998. First evidence of Hercynian Lower Carboniferous flyschoid deep-water sediments in the Lycian Nappes, Southwestern Turkey. Geologica Croatica 51: 15-22.

Kozur H, Aydin M, Demir O, Yakar H, Göncüoglu MC, Kuru F. 2000. New Stratigraphic and Palaeogeographic Results from the Palaeozoic and Early Mesozoic of the Middle Pontides (Northern Turkey) in the Azdavay, Devrekani, Küre and Inebolu Areas: Implications for the Carboniferous-Early Cretaceous Geodynamic Evolution and Some Related Remarks to the Karakaya Oceanic Rift Basin. Geologica Croatica 53(2): 209-268.

Kristan-Tollmann E. 1963. Holothurien-Sklerite aus der Trias der Ostalpen. Sitzungberichte der Akademie der Wissenschaftern in Wien, Abteilung 1, 172: 351-380.

Kristan-Tollmann E. 1971. Weitere Beobachtungen an skulptierten Bairdiidae (Ostrac.) der alpinen Trias. Neues Jahrbuch für Geologie und Paläontologie Abhandlungen 139: 57-81.

Kristan-Tollmann E. 1978. Bairdiidae (Ostracoda) aus den obertriadischen Cassianer Schichten der Ruones-Wiesen bei Corvara in Südtirol. Schriftenreihe der Erdwissenschaftlichen Kommissionen. Österreichische Akademie der Wissenschaften 4: 77-104.

Kristan-Tollmann E. 1983. Ostracoden aus dem Oberanis von Leidapo bei Guiyang in Südchina. Neue Beiträge zur Biostratigraphie der Tethys-Trias 5: 121-176.

Kristan-Tollmann E. 1986a. Triassic of the Tethys and its relations with the Triassic of the Pacific realm. In: McKenzie KG, ed. Shallow Tethys 2. Proceedings of the International Symposium on Shallow Tethys 2, Wagga Wagga, pp. 169-186.

Kristan-Tollmann E. 1986b. Beobachtungen zur Trias am Südostende der Tethys-Papua/Neuguinea, Australien, Neuseeland. Neues Jahrbuch fur Geologie und Palaontologie, Monatshefte 4: 201-222.

Kristan-Tollmann E. 1988a. Unexpected microfaunal communities within the Triassic Tethys. Geological Society of London, Special Publication 37: 213-223.

Kristan-Tollmann E. 1988b. A comparison of Late Triassic agglutinated foraminifera of Western and Eastern Tethys. Abhandlungen der Geologischen Bundesanstalt 41: 245-253.

Kristan-Tollmann E. 1991. Triassic Tethyan microfauna in Dachstein Limestone blocks in Japan. In: Kotaka T, et al., eds. Shallow Tethys 3. International Symposium on Shallow Tethys, Sendai, 1990, Sendai: Saito Ho-on Kai? Special Publication 3, pp. 169-186.

Kristan-Tollmann E. 1993. Zur paläogeographischen Verbreitung der Ostracoden-Gattung Hermiella an der Rhät/Lias-Grenze. Zitteliana 20: 331-342.

Kristan-Tollmann E, Hamedani A. 1973. Eine spezifische Mikrofaunen-Vergesellschaftung aus den Opponitzer Schichten des Oberkarn der niederösterreichischen Kalkvoralpen. Neues Jahrbuch für Geologie und Paläontologie Abhandlungen 143(2): 193-222.

Kristan-Tollmann E, Tollmann A. 1981. Die Stellung der Tethys in der Trias und die Herkunft ihrer Fauna. Mitteilungen der Österreichischen Geologischen Gesellschaft 74/75: 129-135. 
Kristan-Tollmann E, Tollmann A. 1982. Die Entwicklung der Tethystrias und Herkunft ihrer Fauna. Geologische Rundschau 71(8): 987-101.

Kristan-Tollmann E, Tollmann A, Hamedani A. 1979. Beiträge zur Kenntnis der Trias von Persien. I. Revision der Triasgliederung. Rhätfazies in Raum von Isfaham und Kossener Fazieseinschlag bei Waliabad SE Abadeh. Mitteilungen der Österreichischen Geologischen Gesellschaft 70: 119-190.

Kristan-Tollmann E, Tollmann A, Hamedani A. 1980. Beiträge zur Kenntnis der Trias von Persien. II. Zur Rhätfauna von Bagerabad bei Isfahan (Korallen, Ostracoden). Mitteilungen der Österreichischen Geologischen Gesellschaft 73: 163-235.

Kristan-Tollmann E, Haas J, Kovács S. 1991. Karnische Ostracoden und Conodonten der Bohrung Zsámbék-14 im Transdanubischen Mittelgebirge (Ungarn). In: Lobitzer H, Csaszar G, eds. Jubiläumsschrift 20 Jahre Geologische Zusammenarbeit Österreich-Ungarn. Wien: Teil I, pp. 193-219.

Latreille PA. 1806. Genera crustaceorum et insectorum secundum ordinem naturalem in familias disposita. In: Iconibus exemplisque plurimis explicata. Amand Koenig, Parisiis et Argentorati, 303 p.

Liebermann HM. 1979. Die Bivalven- und Ostracodenfauna von Raibl und ihr stratigraphischer Wert. Verhandlungen der Geologischen Bundesanstalt (Wien) 2: 85-131.

Lord AR. 1988. Ostracoda of the Early Jurassic Tethyan Ocean. In: Hanai T, Ikeya N, Ishizaki K, eds. Evolutionary biology of ostracoda: Its fundamentals and applications. Proceedings of the Ninth International Symposium on Ostracoda, Shizuoka, Japan, 1985. Developments in Palaeontology and Stratigraphy 11, Kodansha, Tokyo and Elsevier, Amsterdam, pp. 855-868.

Maddocks RF. 2005. Three new species of podocopid ostracoda from hydrothermal vent fields at $9^{\circ} 50$ 'N on the East Pacific Rise. Micropaleontology 51(5): 345-372.

McKenzie KG. 1982. Palaeozoic-Cenozoic Ostracoda of Tethys. Bollettino della Società Paleontologica Italiana 21(2-3): 311-326.

Méhes G. 1911. Über Trias-Ostrakoden aus dem Bakony. Resultate der wissenschaftlichen Erforschung des Balatonsees. Anhang zu Band 1, Teil 1. Paläontologie der Umgebung des Balatonsees 3: $1-38$.

Mette W, Elsler A, Korte C. 2012. Palaeoenvironmental changes in the Late Triassic (Rhaetian) of the Northern Calcareous Alps: Clues from stable isotopes and microfossils. Palaeogeography, Palaeoclimatology, Palaeoecology 350-352: 62-72.

Mette W, Honigstein A, Crasquin S. 2014. Deep-water ostracods from the Middle Anisian (Reifling Formation) of the Northern Calcareous Alps (Austria). Journal of Micropalaeontology 34: 71-91.

Mirăuță E, Gheorghian D, Badiceanu M. 1993. Données biostratigraphiques sur la Formation de Cataloi (Dobrogea de Nord, Roumanie). Romanian Journal of Stratigraphy 75: 21-27.

Moix P, Kozur H, Stampfli GM, Mostler H. 2007. New palaeontological, biostratigraphical and palaeogeographical results from the Triassic of the Mersin mélange, SE Turkey. New Mexico Museum of Natural History and Science, Bulletin 41: 282-311.

Moix P, Beccaletto L, Kozur H, Hochard C, Rosselet F, Stampfli GM. 2008. A new classification of the Turkish terranes and sutures and its implication for the paleotectonic history of the region. Tectonophysics 451: 7-39.

Moix P, Vachard D, Allibon J, et al. 2013. Palaeotethyan, Neotethyan and Huğlu-Pindos series in the Lycian Nappes (SW Turkey): Geodynamical implications. In: Tanner LH, Spielmann JA, Lucas SG, eds. The Triassic System. New Mexico Museum of Natural History and Science, Bulletin 61, pp. 401-444.
Monod O, Meshur M, Martin M, Lys M. 1983. Découverte de dipnoistes triasiques (Cératodontiformes, Dipnoi) dans la formation de Çenger ("Arkoses rouges") du Taurus lycien (Turquie occidentale). Geobios 16: 161-168.

Monostori M. 1994. Ostracod evidence of the Carnian salinity crisis in the Balaton Highland, Hungary. Neues Jahrbuch für Geologie und Paläontologie 193: 311-331.

Monostori M, Tóth E. 2013. Ladinian (Middle Triassic) silicified ostracod faunas from the Balaton Highland (Hungary). Rivista Italiana di Paleontologia e Stratigrafia 119: 303-323.

Monostori M, Tóth E. 2014. Additional Middle to Upper Triassic ostracod faunas from the boreholes of Transdanubian Central Range (Hungary). Hantkeniana 9: 21-43.

Moore RC. 1961. Treatise on Invertebrate Paleontology. Arthropoda 3, Crustacea, Ostracoda. Geological Society of America and University of Kansas Press.

Müller GW. 1894. Die Ostracoden des Golfes von Neapel und der angrenzenden Meeres Abschnilte. Fauna und Flora Neapel 21: 1404.

Neale JW. 1983. Geological History of the Cladocopina. In: Maddocks R, ed. Applications of Ostracoda. Department of Geosciences, University of Houston, pp. 612-626.

Neubauer F, von Raumer JF. 1993. The Alpine basement - linkage between Variscan and Mediterranean mountain belts. In: Neubauer F, von Raumer JF, eds. Pre-Mesozoic geology in the Alps. Berlin: Springer, pp. 641-663.

Oertli HJ. 1971. The aspect of Ostracode fauna-A possible new tool in petroleum sedimentology. In: Oertli HJ, ed. Paléoécologie des Ostracodes. Bulletin du Centre de Recherche SNPA 5 (Supplement), pp. 137-151.

Ozsvárt P, Dumitrica P, Moix P. 2017. New early Tuvalian (Carnian, Triassic) radiolarians from the Huğlu-Pindos succession in the Sorgun Ophiolitic Mélange, Southern Turkey. Ofioliti 42(1): 55-67.

Poisson A. 1977. Recherches géologiques dans les Taurides occidentales (Turquie). Thèse de doctorat, Université Paris-Sud (Centre d'Orsay), 795 p. (unpublished).

Rigo M, Mazza M, Karádi V, Nicora A. 2018. New Upper Triassic Conodont Biozonation of the Tethyan Realm. In: Tanner LH, ed. The Late Triassic World. Topics in Biology V 46, pp. 189-234.

Robertson AHF, Dixon JE. 1984. Introduction: aspects of the geological evolution of the Eastern Mediterranean. In: Dixon JE, Robertson AHF, eds. The geological evolution of the Eastern Mediterranean. Geological Society London Special Publications 17: 1-74.

Robertson AHF, Karamata S, Šarić K. 2009. Overview of ophiolites and related units in the Late Palaeozoic-Early Cenozoic magmatic and tectonic development of Tethys in the north-ern part of the Balkan region. Lithos 108: 1-36.

Robertson AHF, Parlak O, Ustaömer T. 2013. Late Palaeozoic-Early Cenozoic tectonic development of Southern Turkey and the easternmost Mediterranean region: evidence from the interrelations of continental and oceanic units. Geological Society London Special Publications 372: 9-48.

Salas MJ, Vannier J, Williams M. 2007. Early Ordovician Ostracods from Argentina: their bearing on the origin of Binodicope and Palaeocope clades. Journal of Paleontology 81(6): 1384-1395.

Sars GO. 1866. Oversight af Norges marine Ostracoder. Forhandlinger $i$ Videnskabs- Selskabet $i$ Christiania 1865: 1-130.

Sars GO. 1887. Nye bidrag til kundskaben om middelhavets invertebrafauna: 4. Ostracods mediterranea (sydeuropaeiske ostracoder). Archiv for Mathematik og Naturvidenskab 12: 173-324. 
Sars GO. 1922-1928. An account of the Crustacea of Norway. Volume 9, Crustacea. Bergen Museum 9: 1-277.

Schmid SM, Bernoulli D, Fügenschuh B, et al. 2008. The AlpsCarpathians-Dinarides-connection: a correlation of tectonic unit. Swiss Journal of Geosciences 10(1): 139-183.

Sebe O, Crasquin S, Grădinaru E. 2013. Early and Middle Anisian (Triassic) deep-water ostracods (Crustacea) from North Dobrogea (Romania). Revue de Paléobiologie 32: 509-529.

Senel M. 1997. 1:100 000 ölçekli, Türkiye jeoloji haritalari serisi, $\mathrm{n}^{\mathrm{o}}$ 2. Fethiye - L8 Paftasi, Ankara (Turkey), $30 \mathrm{p}$.

Senel M, Akdeniz N, Öztürk EM, et al. 1994. Fethiye (Muğla)-Kalkan (Antalya) ve kuzeyinin jeolojisi, Maden Tektik ve Arama Enstitüsü, Report n ${ }^{\circ}$ 9761, Ankara.

Sengör AMC. 1984. The Cimmeride orogenic system and the tectonics of Eurasia. Geological Society London Special Publications 195: 1-82.

Spekoski JJJr. 1984. A kinetic model of Phanerozoic taxonomic diversity. Paleobiology 10: 246-267.

Shi CG, Chen DQ. 1987. The Changhsingian ostracodes from Meishan, Changxing, Zhejiang. Stratigraphy and Palaeontology of Systemic Boundaries in China: Permian and Triassic Boundary 1: 23-80.

Shi CG, Chen DQ. 2002. Late Permian ostracodes from Heshan and Yishan of Guangxi. Bulletin of the Nanjing Institute Geology and Paleontology 15: 47-129 [In Chinese with English abstract].

Siveter DJ. 2008. Ostracods in the Palaeozoic? Senckenbergiana Lethaea 88: 1-9.

Stampfli GM, Borel G. 2004. The TRANSMED transects in space and time: constraints on the paleotectonic evolution of the Mediterranean domain. In: Cavazza W,Roure FM, Spakman W, Stampfli GM, Ziegler PA, eds. The TRANSMED Atlas: The Mediterranean region from crust to mantle. Berlin and Heidelberg: Springer, pp. 53-80.

Stampfli GM, Kozur H. 2006. Europe from the Variscan to the Alpine cycles. In: Gee DG, Stephenson RA, eds. European Lithosphere Dynamics. Memoir of the Geological Society, London, pp. 57-82.

Sylvester-Bradley PC. 1961. Suborder Metacopina Sylvester-Bradley, n. suborder. In: Moore RC, ed. Treatise on invertebrate paleontology. Arthropoda 3, Crustacea, Ostracoda. Lawrence, Kansas: Geological Society of America and University of Kansas Press, pp. Q358-Q359.

Urlichs M. 1971. Variability of some ostracods from the Cassian beds (Alpine Triassic) depending on the ecology. In: Oertli HJ, ed. Paléoécologie des Ostracodes. Bulletin du Centre de Recherche SNPA 5 (Supplement), pp. 695-715.
Urlichs M. 1972. Ostracoden aus den Kössener Schichten und ihre Abhängigkeit von der Ökologie. Mitteilungen der Gesellschaft der Geologie und Bergbaustudenten in Österreich 21: 661-710.

Urlichs M, Krystyn L. 2016. Stratigraphic significance of the early Rhaetian ostracods from the proposed Norian/Rhaetian GSSP at Steinbergkogel (late Triassic, Upper Austria). Albertiana 43: 19-23.

Vachard D, Moix P. 2011. Late Pennsylvanian to Middle Permian revised algal and foraminiferan biostratigraphy and palaeobiogeography of the Lycian Nappes (SW Turkey): palaeogeographic implications. Revue de micropaléontologie 54: 141-174.

Vachard D, Moix P. 2013. Kubergandian (Roadian, Middle Permian) of the Lycian and Aladağ Nappes (Southern Turkey). Geobios 46: 335-356.

van den Bold WA. 1946. Contribution to the study of Ostracoda with special reference to the tertiary and cretaceous microfauna of the Caribbean region. Amsterdam: DeBussy.

van den Boogaard M. 1966. Post-Carboniferous conodonts from southeastern Spain. Koninklijke Nederlandse Akademie van Wetenschappen B 69: 691-698.

Van Valen L. 1984. A resetting of Phanerozoic community evolution. Nature 307: 50-52.

Vermeij GJ. 1977. The Mesozoic marine revolution; evidence from snails, predators and grazers. Paleobiology 3: 245-258.

Warne MT, Whatley R. 2016. Neohornibrookella sorrentae (Chapman and Crespin, 1928) and allied ostracod taxa from the Neogene of southeastern Australia: Systematic and palaeoceanographical relationships, palaeoecology and palaeobiogeography. Marine Micropaleontology 125: 110-133.

Yasuhara M, Sztybor K, Rasmussen TL, Okahashi H, Sato R, Tanaka H. 2018. Cold-seep ostracods from the western Svalbard margin: direct palaeo-indicator for methane seepage? Journal of Micropalaeontology 37: 139-148.

Yi WJ. 2004. Ostracodes from the Upper Permian and Lower Triassic at the Kongtongshan section of Datian, Fujian. Acta Palaeontologica Sinica 43: 556-570.

Yuan AH, Crasquin-Soleau S, Feng QL, Gu S. 2009. Ostracods from uppermost Permian siliceous and muddy rocks of Guizhou, Guangxi and Anhui. Acta Micropalaeontologica Sinica 26: 385-403.

Zazzali S, Crasquin S, Deconinck JF, Feng QL. 2015. Biodiversity across the Guadalupian-Lopingian Boundary: first results on the ostracod (Crustacea) fauna, Chaotian section (Sichuan Province, South China). Geodiversitas 37(3): 283-313.

Zorn I. 2010. Ostracodal Type Specimens Stored in the Paleontological Collection of the Geological Survey of Austria. Jahrbuch der Geologischen Bundesanstalt 150(1-2): 263-299.

Cite this article as: Forel M-B, Moix P. 2020. Late Triassic ostracods from the Lycian Nappes, southwestern Turkey: implications on taxonomy and palaeobiogeographical distribution, BSGF - Earth Sciences Bulletin 191: 30. 